Article

\title{
The Impact of the Control Measures during the COVID-19 Outbreak on Air Pollution in China
}

\author{
Cheng Fan ${ }^{1,2}$, Ying $\mathrm{Li}^{3}$, Jie Guang ${ }^{1, *}$, Zhengqiang Li ${ }^{1}\left(\mathbb{D}\right.$, Abdelrazek Elnashar ${ }^{2,4,5}$, \\ Mona Allam $1,2,6 \oplus$ and Gerrit de Leeuw $1,7 \mathbb{1}$
}

1 State Environment Protection Key Laboratory of Satellite Remote Sensing, Aerospace Information Research Institute, Chinese Academy of Sciences, Beijing 100101, China; fancheng@radi.ac.cn (C.F.);

lizq@radi.ac.cn (Z.L.); monaallam@sci.asu.edu.eg (M.A.); gerrit.de.leeuw@knmi.nl (G.d.L.)

2 University of Chinese Academy of Sciences, Beijing 100049, China; abdelrazek.elnashar@cu.edu.eg

3 China Academy of Culture and Tourism, Beijing International Studies University, Beijing 100024, China; liying20190063@bisu.edu.cn

4 State Key Laboratory of Remote Sensing Science, Aerospace Information Research Institute, Chinese Academy of Sciences, Beijing 100094, China

5 Department of Natural Resources, Faculty of African Postgraduate Studies, Cairo University, Giza 12613, Egypt

6 Environment \& Climate Changes Research Institute, National Water Research Center, El Qanater El khairiya 13621/5, Egypt

7 Royal Netherlands Meteorological Institute (KNMI), R\&D Satellite Observations, 3731GA De Bilt, The Netherlands

* Correspondence: guangjie@aircas.ac.cn

Received: 10 April 2020; Accepted: 14 May 2020; Published: 18 May 2020

\begin{abstract}
The outbreak of the COVID-19 virus in Wuhan, China, in January 2020 just before the Spring Festival and subsequent country-wide measures to contain the virus, effectively resulted in the lock-down of the country. Most industries and businesses were closed, traffic was largely reduced, and people were restrained to their homes. This resulted in the reduction of emissions of trace gases and aerosols, the concentrations of which were strongly reduced in many cities around the country. Satellite imagery from the TROPOspheric Monitoring Instrument (TROPOMI) showed an enormous reduction of tropospheric $\mathrm{NO}_{2}$ concentrations, but aerosol optical depth (AOD), as a measure of the amount of aerosols, was less affected, likely due to the different formation mechanisms and the influence of meteorological factors. In this study, satellite data and ground-based observations were used together to estimate the separate effects of the Spring Festival and the COVID-19 containment measures on atmospheric composition in the winter of 2020. To achieve this, data were analyzed for a period from 30 days before to 60 days after the Spring Festivals in 2017-2020. This extended period of time, including similar periods in previous years, were selected to account for both the decreasing concentrations in response to air pollution control measures, and meteorological effects on concentrations of trace gases and aerosols. Satellite data from TROPOMI provided the spatial distributions over mainland China of the tropospheric vertical column density (VCD) of $\mathrm{NO}_{2}$, and $\mathrm{VCD}$ of $\mathrm{SO}_{2}$ and $\mathrm{CO}$. The MODerate resolution Imaging Spectroradiometer (MODIS) provided the aerosol optical depth (AOD). The comparison of the satellite data for different periods showed a large reduction of, e.g., $\mathrm{NO}_{2}$ tropospheric VCDs due to the Spring Festival of up to $80 \%$ in some regions, and an additional reduction due to the COVID-19 containment measures of up to $70 \%$ in highly populated areas with intensive anthropogenic activities. In other areas, both effects are very small. Ground-based in situ observations from 26 provincial capitals provided concentrations of $\mathrm{NO}_{2}, \mathrm{SO}_{2}, \mathrm{CO}, \mathrm{O}_{3}, \mathrm{PM}_{2.5}$, and $\mathrm{PM}_{10}$. The analysis of these data was focused on the situation in Wuhan, based on daily averaged concentrations. The $\mathrm{NO}_{2}$ concentrations started to decrease a few days before the Spring Festival and increased after about two weeks, except in 2020 when they continued to be low. $\mathrm{SO}_{2}$ concentrations behaved in a similar way, whereas $\mathrm{CO}, \mathrm{PM}_{2.5}$, and $\mathrm{PM}_{10}$ also
\end{abstract}


decreased during the Spring Festival but did not trace $\mathrm{NO}_{2}$ concentrations as $\mathrm{SO}_{2}$ did. As could be expected from atmospheric chemistry considerations, $\mathrm{O}_{3}$ concentrations increased. The analysis of the effects of the Spring Festival and the COVID-19 containment measures was complicated due to meteorological influences. Uncertainties contributing to the estimates of the different effects on the trace gas concentrations are discussed. The situation in Wuhan is compared with that in 26 provincial capitals based on 30-day averages for four years, showing different effects across China.

Keywords: air pollution; Spring Festival; COVID-19

\section{Introduction}

As the world's largest developing country, China has achieved enormous economic development since the 1980s, to become the second-largest economy in the world, after the USA, with a gross domestic product (GDP) of 99.1 trillion RMB (14.41 trillion US\$) in 2019. China's per capita GDP also exceeded that of the USA by US $\$ 10,000$ for the first time [1]. The fast-growing economy, urbanization, socioeconomic development, and associated growth of motorized vehicles have a huge impact on the air quality (AQ), especially in a number of highly industrialized and populated centers in southeastern China. During the last decades, the Chinese government has attached great importance to environmental issues and has adopted a series of policy measures to reduce China's air pollution (e.g., [2,3]). The effects of these measures are visible in satellite measurements of trace gases and aerosols. In particular, the long time series of aerosol optical depth (AOD) measurements, combining data from three sensors, show the initial increase until 2006, and the substantial decrease from 2011 [4,5]. The launch of the Dutch/Finnish Ozone Monitoring Instrument (OMI) in 2004 has facilitated the observation of long time series of $\mathrm{SO}_{2}$ and $\mathrm{NO}_{2}$, which show that policy measures resulted in a substantial decrease of $\mathrm{SO}_{2}$ from 2006, and of $\mathrm{NO}_{2}$ from 2014 [2]. The trend analyses for $\mathrm{SO}_{2}$ and $\mathrm{NO}_{2}$ [2], and for AOD [3], also show the regional differences in the effectiveness of the pollution control measures across China. For the confirmation of these satellite observations, as well as to quantify the trends near the surface, long-term ground-based measurements of concentrations of aerosols and trace gases are needed. However, until 2013, such long-term observations were available for only a few locations across the country (see [6] for an overview of studies since 1998). In 2013, the Ministry of Ecology and Environment of the People's Republic of China (MEE) established a ground-based AQ monitoring network with in situ measurements at more than 1000 sites, and the data are publicly available (see Section 3.1). The analysis of $\mathrm{PM}_{2.5}$ (the aerosol mass concentration of dry particles with an in situ diameter of $2.5 \mu \mathrm{m}$; PM10 is the same for diameter smaller than $10 \mu \mathrm{m}$ ) data from the MEE network over a 6-year period (2013-2018) shows a large reduction by $30 \%-50 \%$ of the annual mean $\mathrm{PM}_{2.5}$ across China, confirming the satellite-derived AOD trends [7]. Other analyses confirm the decrease of $\mathrm{PM}_{2.5}, \mathrm{PM}_{10}, \mathrm{SO}_{2}$, and $\mathrm{CO}$ concentrations and the increase of $\mathrm{O}_{3}$ concentrations in the period 2015-2017. For $\mathrm{NO}_{2}$, the changes during that period were variable with no overall trend across China $[8,9]$.

These long-term trend studies describe the effects of control measures, which are meant to be effective over a long period of time. Complementary to these, rigorous measures were taken to reduce air pollution during specific events, such as the 2008 Olympic games in Beijing [10], the 2010 Guangzhou Asian Games [11], the 2014 Youth Olympic Games in Nanjing [12], the 2014 Asian Pacific Economic Cooperation Conference (APEC) [13], and the 2015 China Victory Day parade [14]. During these events, air quality was substantially improved, and the results were used in scientific studies on the effect of emission control.

These are local events while in the rest of the country activities continue as usual. Therefore, only the effects of the reduction of local emissions on the concentrations are observed, whereas the effects of (long-range) transport and meteorological factors continue to influence the concentrations. 
In contrast, during nation-wide events, such as the National Holiday and the Chinese Spring Festival, emissions change due to the migration of a large part of the population to their families, often far away from their work or school, and temporary reduction of economic activities in the whole country, rather than due to local measures. The largest event in China is the Spring Festival, when the migration starts about two weeks before the event when the first people travel home, often over long distances, and lasts for about 2-3 weeks after the festival when people return to their workplaces. This results in increased long-distance traffic before and after the Spring Festival while at the same time local traffic in the cities is gradually reduced. A majority of factories and businesses stop their activities for 1-2 weeks, throughout the whole country, except for activities vital to people's basic needs and the operation of the city. Past observations show that air pollution during this period decreases but once the Spring Festival is over, air pollution rapidly increases back to normal levels [15-18]. In 2020, the situation was different because of the COVID-19 virus outbreak just before the Spring Festival when many people had already traveled home, and factories were closed. Based on experiences from earlier coronavirus outbreaks, i.e., SARS in 2003 [19] and MERS in 2012 [20], the Chinese government adopted the strictest control measures to minimize the spread of the virus, especially in Wuhan, Hubei, where the outbreak originated. These measures started on 23rd January, two days before the Chinese New Year in 2020. After the Spring Festival holiday, this control was enforced for about 2 months when travel was restricted, factories gradually started up with long delay, offices remained closed until early March, and schools and universities even longer. The measures in Wuhan were relaxed only around 25 March when the roads around the city were opened, with the first trains arriving on 28 March and Wuhan was unlocked on 8 April although certain restriction was still maintained. According to the statistics from China's Ministry of Transport (http://www.mot.gov.cn/, last access: 5 April 2020), traffic during the 2020 Spring Festival dropped by more than $50 \%$ in all of China compared to that in the previous year. Almost all industrial plants were closed in Wuhan.

As a result, the 'normal' Spring Festival effect on air quality was reinforced and extended by the government measures to minimize the spreading of the virus, i.e., the effective lock-down of most of the country. Emissions of aerosols and trace gases were largely reduced as reported in the media based on satellite observations [21-24]. In this study, the effects of the almost complete lock-down on air quality is described, based on satellite observations and ground-based measurements. The spatial and temporal distributions of the concentrations of aerosols and trace gases during an extended period around the 2020 Spring Festival are compared with those in previous years, to obtain a clear understanding of the impact of the government measures on the air quality in several cities in China.

\section{Study Area}

The study area is China's mainland, which covers the land area between $15^{\circ} \mathrm{N}-54^{\circ} \mathrm{N}$ and $73^{\circ} \mathrm{E}-136^{\circ} \mathrm{E}$. The population map of China (Figure 1) shows that the vast majority of China's population is located to the south-east of the Hu Huan-Yong (henceforth termed HU Line) [25], in particular the North China Plain (NCP), the Yangtze River Delta (YRD), the Pearl River Delta (PRD), Sichuan Province, the Guanzhong Basin, and central China in the provinces Hubei and Hunan (see Figure S1 for a provincial map of China and regions). Most of China's megacities and much industry are situated in these areas, resulting in a high density of motorized traffic. These intensive human activities result in emissions, leading to the deterioration of air quality. Air pollution in China is high in the east and low in the west as described in detail by [26] for $\mathrm{NO}_{2}$ and by [27] for aerosols. However, spatial patterns are different for each species, cf. the satellite spatial distribution maps for $\mathrm{NO}_{2}, \mathrm{SO}_{2}$, and $\mathrm{CO}$ in Section 4.1 and the Supplementary Material. The temporal variation was studied by comparison of satellite data for different periods, and in more detail by using ground-based observations in the 26 provincial capitals in central and eastern China, see Figure 1. 


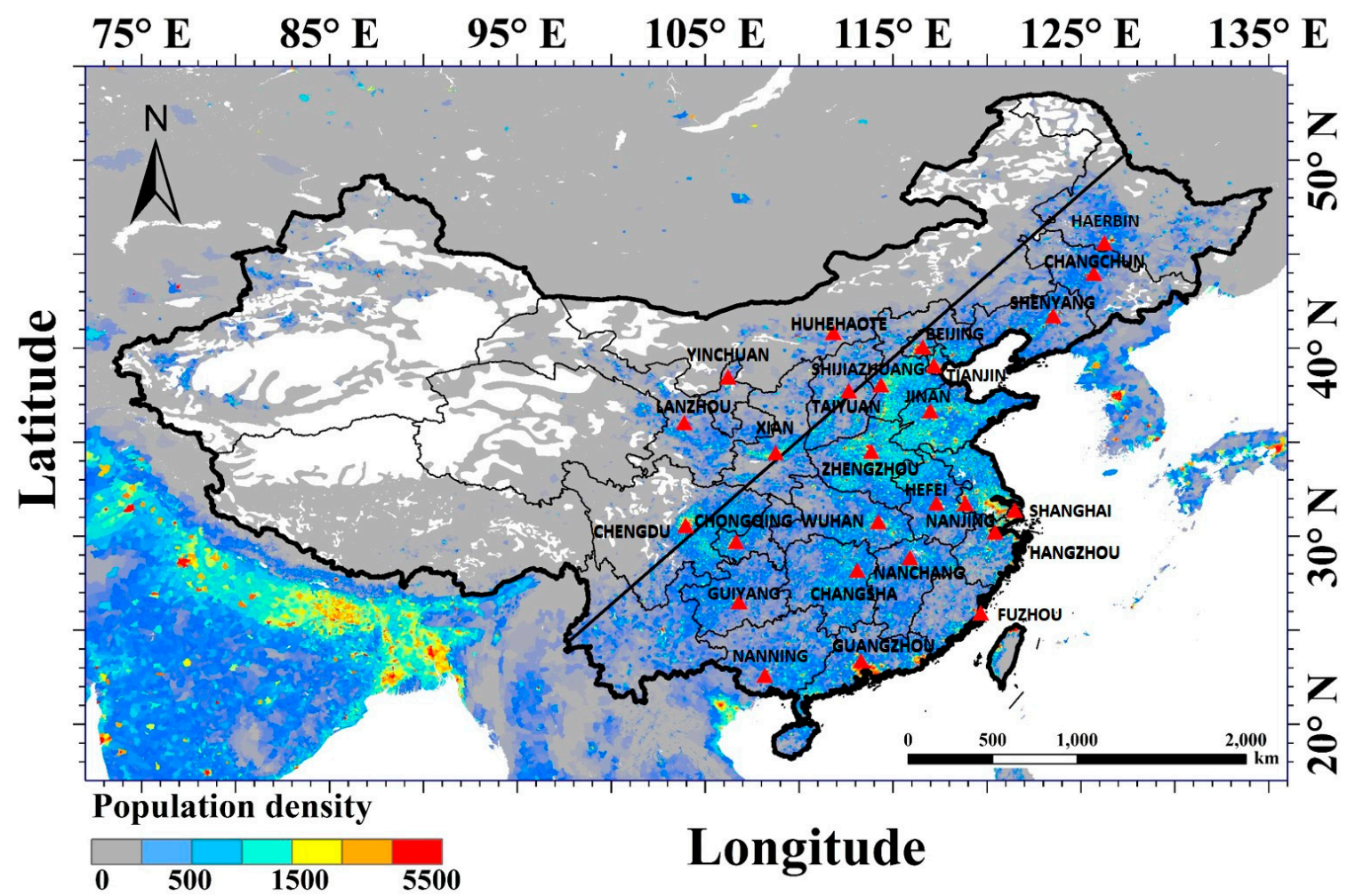

Figure 1. Population density (people per $\mathrm{km}^{2}$ ) map for China with a total of 1.4005 billion people (http://sedac.ciesin.columbia.edu/data/collection/gpw-v4/sets/browse). The red triangles show the 26 provincial capitals which are used in this study for comparison with detailed results for Wuhan. The line is the HU Line, which divides China in eastern and western parts.

\section{Data Description}

\subsection{Ground-Based Data}

The ground-based data used in this research were downloaded from http://www.pm25.in/ (last access: 27 April 2020), which is the National Real-time Air Quality Publishing Platform public website for air quality monitoring data maintained by the China National Environmental Monitoring Center (CNEMC) of the Ministry of Ecology and Environment of China (MEE, see http://www.mee.gov.cn/, last access: 27 April 2020, for more detail). This website provides $\mathrm{PM}_{2.5}, \mathrm{PM}_{10}, \mathrm{SO}_{2}, \mathrm{NO}_{2}, \mathrm{O}_{3}$, and $\mathrm{CO}$ hourly and 24-h moving averages for each site or city. Measurement techniques used at the stations, reliability of the data and quality control were briefly described by [8] and [7]; see also (Ministry of Environmental Protection of the People's Republic of China, 2012) [28]. The data from these websites are provided by local governments and have been used in several studies related to air pollution, air quality, and other aspects in China [29,30] (http://www.pm25.in/sharer, last access: 27 April 2020). For the current study, we collected hourly $\mathrm{PM}_{2.5}, \mathrm{PM}_{10}, \mathrm{SO}_{2}, \mathrm{NO}_{2}, \mathrm{O}_{3}$, and $\mathrm{CO}$ data for 370 cities, with the main focus on the 26 provincial capitals in eastern and central China as indicated in Section 2 and Figure 1, for the period of 30 days before and after the Spring Festival, for the years 2017-2020. Because the Spring Festival is determined by the phases of the moon [31], these periods are not on the same dates of the solar calendar, as shown in Table 1. Note that the COVID-19 virus was discovered in Wuhan on 30 December 2019 [32], i.e., within the 30-day period. In the current study, the data collected at different locations in each city were averaged to get a spatially representative number for the whole city, as daily (24 h) averages. 
Table 1. Study period for 2017-2020.

\begin{tabular}{ccccc}
\hline Year & Start (-30d) & Spring Festival & End (+30d) & Extend (+60d) \\
\hline 2017 & 29 December 2016 & 28 January & 27 February & $/$ \\
2018 & 17 January & 16 February & 18 March & $/$ \\
2019 & 6 January & 5 February & 7 March & 6 April \\
2020 & 26 December 2019 & 25 January & 24 February & 25 March \\
\hline
\end{tabular}

\subsection{Satellite Data}

Satellite data used in this study are from the TROPOspheric Monitoring Instrument (TROPOMI). For AOD, MAIAC products were used for 2019 and 2020. The data were downloaded for a period of 30 days before and after the Spring Festivals in 2019 and 2020 to cover the traffic rush periods of 15 days before and 25 days after the Spring Festival. Satellite data were processed using the Google Earth Engine (GEE) cloud computing platform [33] and the ArcGIS platform [34].

\subsubsection{TROPOMI Data}

TROPOMI is a passive hyperspectral nadir-viewing imager aboard the Sentinel-5 Precursor satellite (also known as Sentinel-5P) launched on 13 October 2017 [35]. Sentinel-5P is a near-polar orbiting sun-synchronous satellite flying at an altitude of $817 \mathrm{~km}$ in an ascending node with an equator crossing time at 13:30 LT and a repeat cycle of 17 days. The swath width is approximately $2600 \mathrm{~km}$, resulting in daily global coverage, with an along-track resolution of $7 \mathrm{~km}$ [35]. TROPOMI products used in this study are L3 off-line (OFFL) version products (see http://www.TROPOMI.eu/data-products/ for more detail): tropospheric $\mathrm{NO}_{2}$ column density data, $\mathrm{SO}_{2}$ total vertical column data, and the vertical integrated column density of CO, for the period around the 2019 and 2020 Spring Festivals. The spatial resolution at nadir for most products used in this study is $3.5 \times 7 \mathrm{~km}^{2}$, except for CO for which it is $7 \times 7 \mathrm{~km}^{2}$.

The operational validation results are reported every 3 months at the S5P-MOC-VDAF website (http: //mpc-vdaf.TROPOMI.eu/, last access: 6 April 2020). The TROPOMI/S5P tropospheric $\mathrm{NO}_{2}$ column is operationally validated by the S5P-MPC-VDAF (S5P-Mission Performance Centre - Validation Data Analysis Facility) using the Pandora $\mathrm{NO}_{2}$ total columns from the Pandonia Global Network (PGN). The comparison shows a negative bias of roughly $30 \%$. The TROPOMI/S5P SO $\mathrm{S}_{2}$ column data are found in generally good agreement with ground-based measurements and with other satellite observations. The bias and dispersion with respect to validation data are smaller than $0.2 \mathrm{DU}$. The TROPOMI/S5P total CO column data is in good overall agreement with correlative measurements from the NDACC and TCCON FTIR monitoring networks, with a positive bias of approximately $10 \%$ (NRTI, before July 2019) or 6\% (OFFL) on average.

\subsubsection{MODIS Data}

The MODIS (MODerate resolution Imaging Spectroradiometer) [36] was launched aboard NASA's Terra (launch 1999) and Aqua (launch 2002) satellites in a near-polar sun-synchronous circular orbit. Terra has a daytime equator crossing time at 10:30 LT in a descending node and Aqua at 13:30 LT in an ascending node. MODIS has a swath of $2330 \mathrm{~km}$ (cross track) and provides near-global coverage on a daily basis. MODIS is an imaging radiometer with 36 wavebands, covering the wavelength range from the ultraviolet to the thermal infrared. One of the most successful products of MODIS, which has been used in numerous aerosol-related studies, is the aerosol optical depth at $550 \mathrm{~nm}$. The aerosol optical depth (AOD) data used in this study is the MCD19A2 product, which is a MODIS/Terra and MODIS/Aqua combined aerosol optical depth (AOD) retrieved with the multiangle implementation of atmospheric correction (MAIAC) algorithm [37,38]. The MAIAC algorithm uses time series and spatial analysis to improve the coverage and accuracy, which is important in the current study over China in the wintertime when AOD and cloud percentages are high. The MAIAC AOD retrieval has 
been evaluated over south Asia and China (e.g., [39-41]) and has been used for air quality studies in China (e.g., [42,43]). For the current study, MAIAC data on a 1-km grid were downloaded from the NASA's Land Processes Distributed Active Archive Center (https://pdaac.usgs.gov/data/) for the Spring Festival study periods in 2019 and 2020, and resampled to a 10-km spatial resolution by the pixel average.

\section{Results}

In this section, satellite observations, providing a spatial view of the concentrations of pollutants before, during, and after the Spring Festival in two years, 2019-2020, are presented and discussed. For 2020, we looked at the extended period after the Spring Festival to see the effect of the measures to contain the COVID-19 outbreak from the comparison with the previous year. Next, in Section 4.2, the time series of daily averaged ground-based concentrations measured in selected cities are presented together with daily satellite data, for the periods 2017-2020, to investigate how the concentrations evolved in time.

\subsection{Satellite Observations}

\subsection{1. $\mathrm{NO}_{2}$}

Maps of the spatial distribution of tropospheric $\mathrm{NO}_{2}$ vertical column densities (VCDs) over China, averaged over 30 days (TNO2_ave) before and after the Spring Festival, are shown for 2019 and 2020 in Figure 2. The spatial distribution of the TNO2_ave for 2019 before the Spring Festival (Figure 2a) reflects that of the population density (Figure 1) and was discussed in detail by [26] in terms of regional heating, industry, geographical conditions, and socioeconomic background. In addition to the large urban agglomerations covering the NCP and YRD, there are several regional hotspots with high tropospheric $\mathrm{NO}_{2}$ concentrations, on the order of $27 \times 10^{15}$ molec. $\cdot \mathrm{cm}^{-2}$, such as provincial capitals and regional centers (refer to Figure 1 and Section S1 for the locations of the regions, provinces, and cities mentioned henceforth). Another area with high TNO2_ave is observed in the northwest of China. After the 2019 Spring Festival (Figure 2b), similar spatial patterns are observed but concentrations are substantially lower, especially in the $\mathrm{BTH}$ area and Shandong province (varying from about $10 \times 10^{15}$ molec. $\cdot \mathrm{cm}^{-2}$ to $24 \times 10^{15}$ molec. $\cdot \mathrm{cm}^{-2}$ ). Hence, the Spring Festival resulted in an overall reduction of the $\mathrm{NO}_{2}$ tropospheric VCDs by about a factor of 2 . To quantitatively show the differences and their spatial variation, a map was produced showing the pixel-by-pixel ratio of the TNO2_ave after the Spring Festival to that before (Figure S2a). The map in Figure S2a confirms that the largest TNO2_ave reductions, by about $50 \%$ of the concentration before the festival, occurred over areas with high population densities, and even larger, up to in $70-80 \%$, in some other areas (see Section S2 for more detail). This comparison shows that there is a clear effect of the 2019 Spring Festival on the TNO2_ave concentrations over China. Comparison of similar maps covering a small period during the 2019 Spring Festival (4-10 February 2019) and another one starting 2 weeks after (17 February-17 March 2019) (not shown here) shows that the concentrations quickly recover once normal life in China is resumed.

In 2020, the Spring Festival effect on $\mathrm{NO}_{2}$ emissions and concentrations was augmented and extended due the measures to contain the COVID-19 outbreak. However, the starting point was also quite different: The 2020 Spring Festival was about 2 weeks earlier than in 2019, i.e., closer to the winter peak when $\mathrm{NO}_{2}$ concentrations are usually higher than later in the year, e.g., [26]. The data in Figure 2c show that the TNO2_ave column densities were overall substantially lower than in 2019 (Figure 2a) and also spatially the differences were large. In particular, the area with high TNO2_ave column densities extended much further south in 2019 than in 2020 (compare Figure 2a,c). In the period after the 2020 Spring Festival, the atmosphere over China was effectively cleaned from $\mathrm{NO}_{2}$ as the map in Figure 2d shows: The tropospheric VCDs dropped from 12-18 $\times 10^{15}$ molec. $\mathrm{cm}^{-2}$, and locally $27 \times 10^{15}$ molec. $\cdot \mathrm{cm}^{-2}$ to about $3-6 \times 10^{15}$ molec. $\cdot \mathrm{cm}^{-2}$, with the highest values of about $10 \times 10^{15}$ molec. $\cdot \mathrm{cm}^{-2}$. In other words, the VCDs were overall a factor of 3-4 lower after the Spring 
Festival than before. The large difference with 2019 is caused by the extended period of low emissions due to the lock-down and hence the recovery observed in 2019 did not occur. Comparison of Figure 2b,d shows the large difference between the combined Spring Festival and lock-down effects in 2020 and that of the Spring Festival alone in 2019, i.e., the substantial effect of the COVID-19 containment measures on the TNO2_ave column densities with a much stronger reduction over a much larger area.
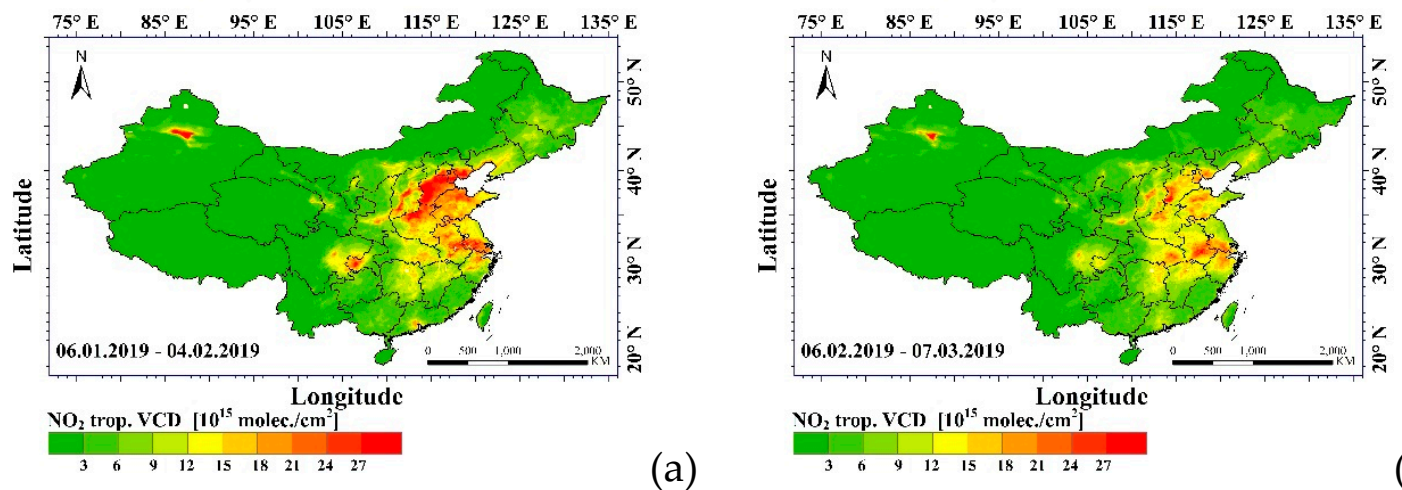

(a)
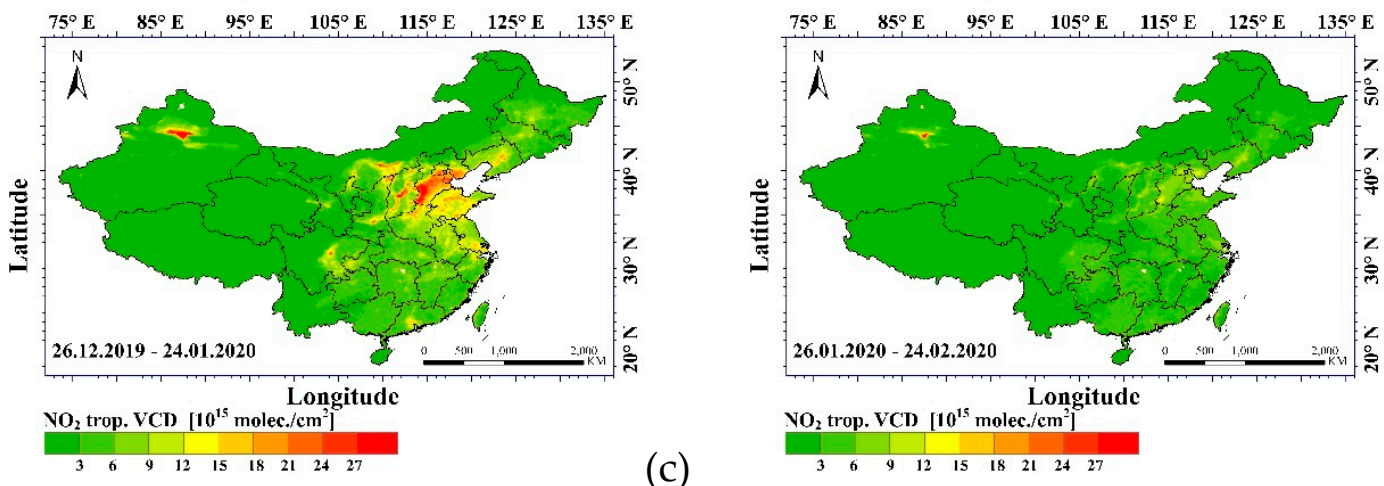

Figure 2. $\mathrm{NO}_{2}$ tropospheric vertical column density averaged over 30 days: (a) before the 2019 Spring Festival; (b) after the 2019 Spring Festival; (c) before the 2020 Spring Festival; (d) after the 2020 Spring Festival.

Quantitatively, the ratio of the TNO2_ave column densities after the 2020 Spring Festival to those before (Figure S2b) shows the large reduction to $40-50 \%$ and in some regions even $70-80 \%$ of the concentration before the festival (from $15-17 \times 10^{15}$ molec. $\cdot \mathrm{cm}^{-2}$ to $5-7 \times 10^{15}$ molec. $\cdot \mathrm{cm}^{-2}$ or less). The reduction pattern shown in Figure 2 and Figure S2 reflects the substantial reduction of economic activity and human migration in that period. Figure S2d shows the ratio of the TNO2_ave after the Spring Festival in 2020 to that in 2019.

To quantitatively estimate the effect of measures to contain the COVID-19 outbreak, it must be separated from the Spring Festival effect. To this end, the Spring Festival effect was estimated by using the TNO2_ave concentrations before and after the Spring Festival in 2019 together with those before the 2020 Spring Festival:

$$
X_{2020 a f t e r, e s t}=X_{2020 b e f o r e} \frac{X_{2019 a f t e r}}{X_{2019 b e f o r e}}
$$

where $\mathrm{X}$ represents $\mathrm{TNO} 2$ _ave, but it can also be done for other species like $\mathrm{SO}_{2}, \mathrm{CO}$, or AOD. In this exercise, we assume that the Spring Festival effect is the same in both years, but the starting point may be different due to effective emission reduction measures, which reduced the $\mathrm{NO}_{2}$ emissions since 2014 [2] or due to meteorological factors [7]. Equation (1) provides TNO2_ave taking into account the emission reduction due to the Spring Festival holidays. The TNO2_ave observations after the Spring 
Festival holidays in 2020 include the additional effect of the virus containment measures, and therefore the difference between the estimated and observed TNO2_ave provides an estimate of the effect of the virus containment measures on the TNO2 concentrations:

$$
\text { diff } f_{2020-2019}=\frac{X_{2020 a f t e r, \text { real }}-X_{2020 a f t e r, \text { est }}}{X_{2020 a f t e r, \text { set }}}
$$

The results, presented in Figure 3, show a substantial effect over most of China east of about $107^{\circ} \mathrm{E}$ and in the northwest, with an estimated reduction of the concentrations of tropospheric $\mathrm{NO}_{2}$ VCDs on the order of 50\%-70\%. See Section S2.3 for more regional detail.

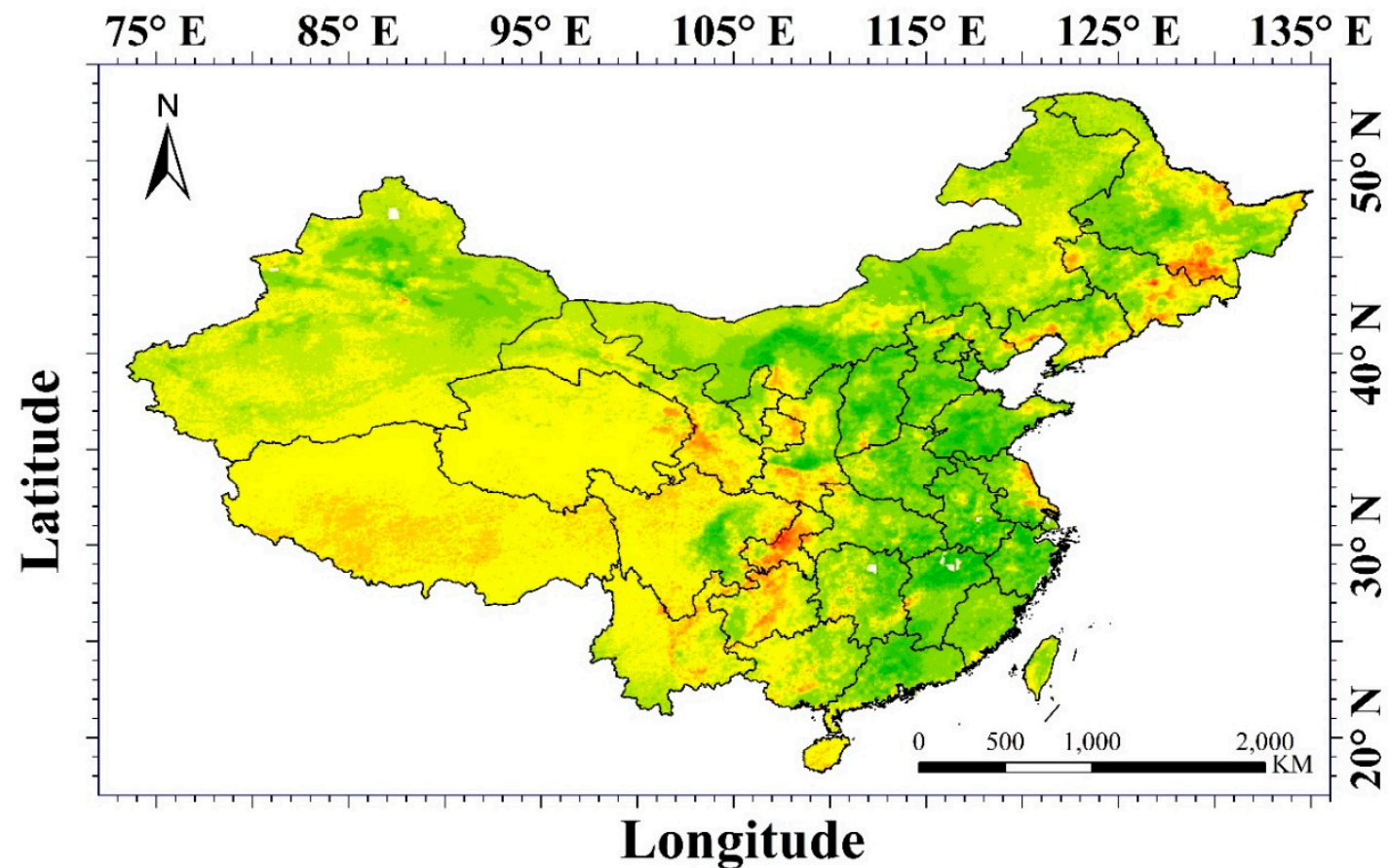

Relative change in $\mathrm{NO}_{2}$ trop. VCD

$\begin{array}{llllllllll}-0.8 & -0.6 & -0.4 & -0.2 & -0.1 & 0.1 & 0.2 & 0.4 & 0.6 & 0.8\end{array}$

Figure 3. Estimated effect of the virus containment measures on the TNO2_ave concentrations over China: green colors indicate a reduction, red colors indicate enhancement; light colors (yellow) indicate no or little effect (see color scale for values).

\subsection{2. $\mathrm{SO}_{2}$ and $\mathrm{CO}$}

The 30-day averages of the TROPOMI-retrieved $\mathrm{SO}_{2}$ VCDs for 2019 and 2020 before and after the Spring Festival (Figure S3) show the substantial reduction of the $\mathrm{SO}_{2} \mathrm{VCD}$. Like for $\mathrm{NO}_{2}$, the highest $\mathrm{SO}_{2}$ VCDs before the Spring Festival and in both years were observed over the NCP and the Junggar Basin, with values on the order of $27 \times 10^{15}$ molec. $\cdot \mathrm{cm}^{-2}$. After the 2019 Spring Festival, similar values were observed in these regions but over much smaller areas, indicating the contribution of local emissions to the high $\mathrm{SO}_{2}$ VCDs, likely from essential industries, such as power generation. In surrounding areas, the $\mathrm{SO}_{2}$ VCDs were reduced to $16 \times 10^{15} \mathrm{molec} \cdot \mathrm{cm}^{-2}$ or less $[44,45]$.

In 2020, the $\mathrm{SO}_{2}$ VCD map before the Spring Festival shows that the concentrations were overall higher, in particular in the north of China, but hotspots occurred with values similar to those in 2019. However, after the 2020 Spring Festival, the concentrations were substantially lower and with large spatial differences, which make it hard to quantify the overall effect (compare Figure S3e,d) and separate the effects due to the Spring Festival and the COVID-19 measures, as was done for $\mathrm{NO}_{2}$. 
Over areas with high $\mathrm{SO}_{2}$ VCDs, the effect of the COVID-19 measures was estimated to be on the order of $20-50 \%$.

Maps of TROPOMI-derived CO VCDs, averaged over 30 days before and after the Spring Festivals in 2019 and 2020 (Figure S4), show the spatial distribution over China. In contrast to $\mathrm{NO}_{2}$ and $\mathrm{SO}_{2}$, the CO VCDs after the 2019 Spring Festival are overall not much different from those before, apart from some local differences. Over the highly industrialized area in Eastern China, the concentrations were on the order of $42 \times 10^{17}$ molec. $\cdot \mathrm{cm}^{-2}$ or larger and close inspection of the maps shows that locally, near the east coast, they had even increased somewhat after the Spring Festival whereas near the south coast they decreased. In 2020, the situation was similar, both as regards the VCDs before and after the Spring Festival, with some changes in the spatial distribution. After the Spring Festival, the CO VCDs were somewhat lower, except in the southern provinces where they were actually a bit higher than before.

These observations lead to the conclusion that the CO VCDs are not very sensitive to short-term changes in anthropogenic emissions, as expected for a gas with an atmospheric life time of about 1-2 months [46]. On a longer term, the lock-down effects did become visible in CO VCDs, as illustrated in Figure S4f, which shows the difference between the CO VCDs between the second and the first period of 30 days after the Spring Festival. For instance, in the NCP, the CO VCD is reduced from more than $42 \times 10^{17}$ molec. $\cdot \mathrm{cm}^{-2}$ before the Spring Festival to about $30 \times 10^{17}$ molec. $\mathrm{cm}^{-2}$ in the second 30-day period, while further south the CO VCDs actually increase.

The analysis to estimate the impact of the COVID-19 measures on the TNO2_ave, described above in Section 4.1.1, was repeated for CO. The results in Figure 4 show that the estimated effect of the COVID-19 measures on the CO VCDs is small, mostly less than $\pm 20 \%$, and rather homogeneously distributed across the whole country, except for the southern provinces and in the northwest where CO concentrations increased, with up to about $50 \%$.

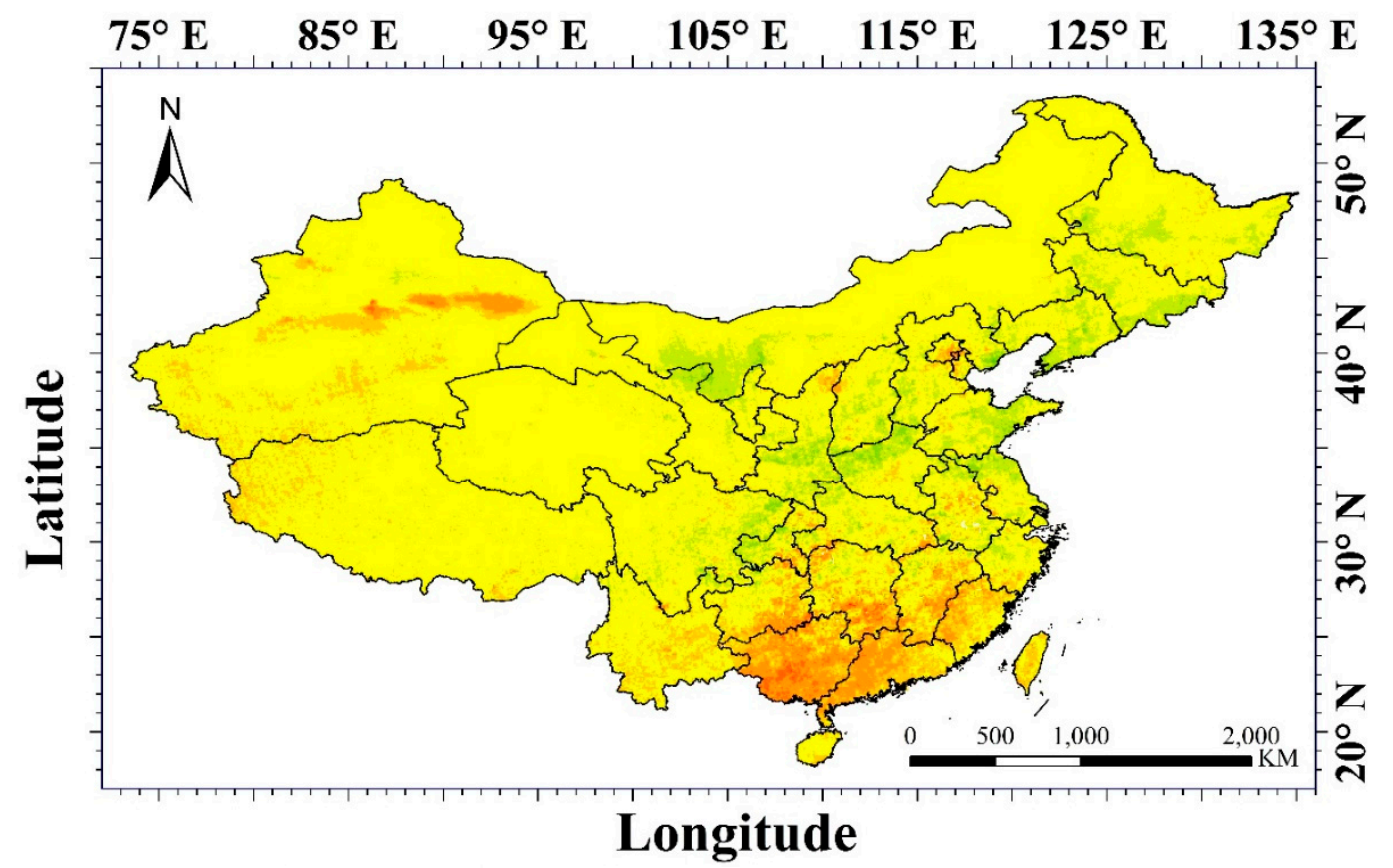

Relative change in CO VCD

$\begin{array}{llllllllll}-0.8 & -0.6 & -0.4 & -0.2 & -0.1 & 0.1 & 0.2 & 0.4 & 0.6 & 0.8\end{array}$

Figure 4. The same as Figure 3 but for CO. 


\subsubsection{AOD}

Aerosols are an important component of the air quality index though the particulate matter mass concentration of dry particles with an in situ diameter of $2.5 \mu \mathrm{m}\left(\mathrm{PM}_{2.5}\right) . \mathrm{PM}_{2.5}$ cannot be directly observed from satellites and is not directly correlated with other satellite-derived aerosol parameters, such as AOD. The relation between $\mathrm{AOD}$ and $\mathrm{PM}_{2.5}$ depends on meteorological conditions as well as aerosol spectral composition determining the column-integrated optical properties as observed by satellites and the aerosol mass near the surface as measured in situ (e.g., [7,47-49]) and this relation varies across China (e.g., [49]). Figure 5 shows AOD maps derived from MODIS observations using the MAIAC method, averaged over 30 days before and after the Spring Festivals in 2019 and 2020. It is noted that the 2020 maps show little coverage north of $40^{\circ} \mathrm{N}$, where only few data are available.
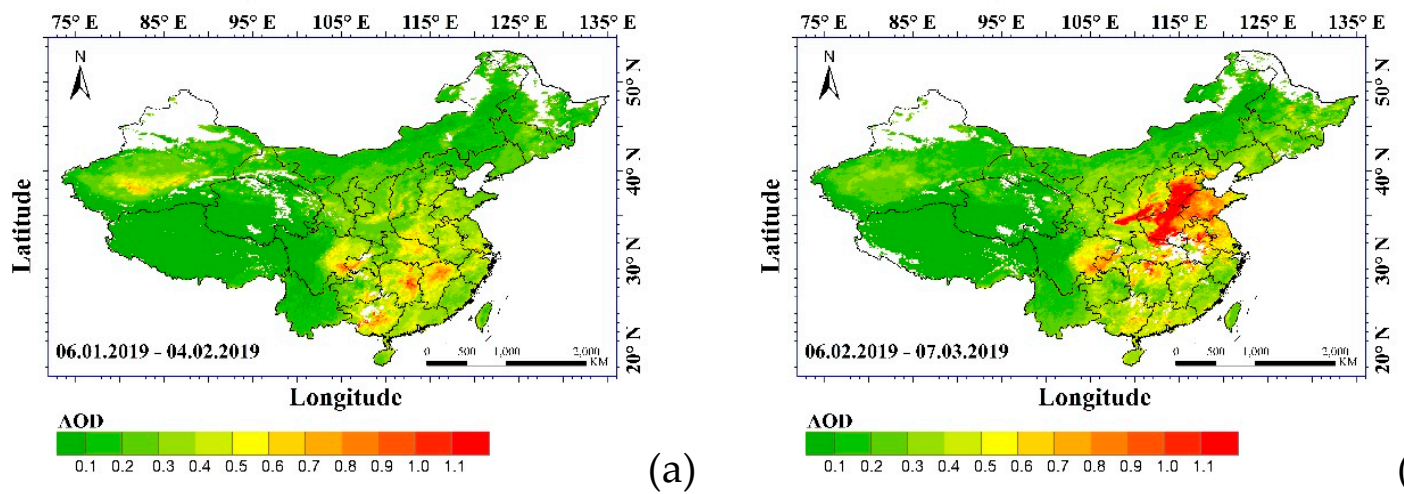

(a)
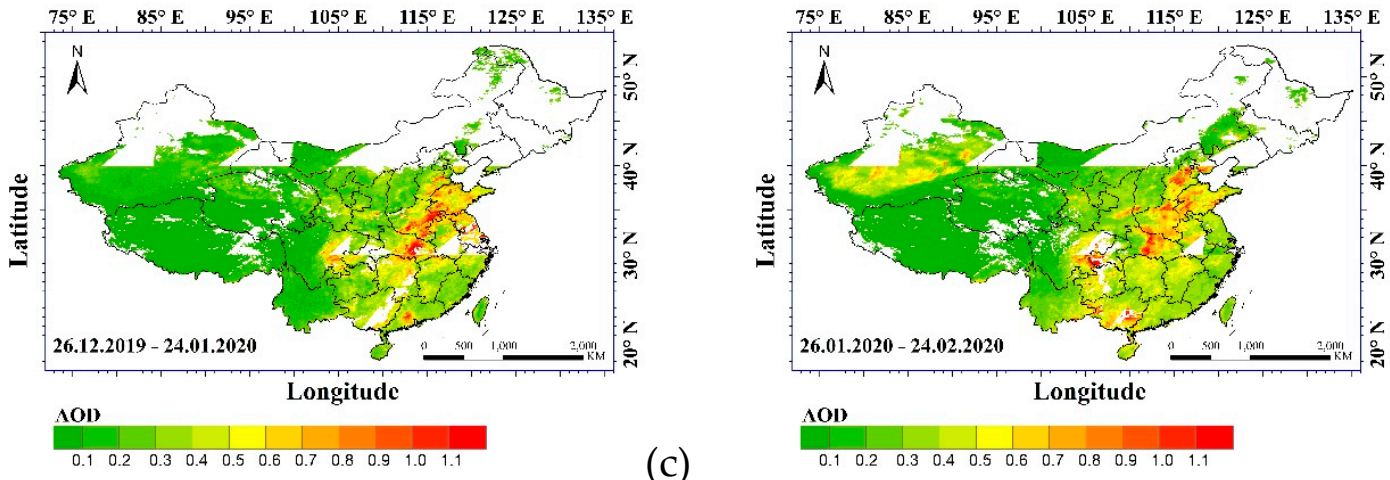

(c)

Figure 5. Same as Figure 2 but for AOD.

The AOD data for 2019 show the spatial distribution of AOD across China, similar to earlier observations, e.g., [4]. The AOD maps for 2019 clearly show the enhanced AOD over the Taklamakan desert (western China), i.e., desert dust emitted and lifted to a high elevation, which is subsequently transported eastward to the BTH region where the highest AOD is observed due to contributions from both desert dust and anthropogenic aerosols [50]. AOD is high over most of southeastern China, with values ranging from about 0.4 to 0.9 . However, as opposed to the trace gas concentrations, the AOD after the Spring Festival in 2019 is substantially higher over the NCP and adjacent provinces, with values of up to 1 and more. This is anticipated to be due to meteorological factors, such as stagnant air with little transport or vertical mixing in a low planetary boundary layer, which often occurs in winter, and high relative humidity. These meteorological factors are conducive to the formation of haze [51] and the intensification of the occurrence of haze in the NCP [52].

In 2020, the AOD over southeastern China was variable and reached values of up to $0.8-0.9$, both before and after the Spring Festival, with some differences in the spatial distributions. No significant differences are observed between these two periods, except for the lower AOD over the Taklamakan 
desert in the period after the Spring Festival. The AOD after the Spring Festival was lower in 2020 than in 2019, but based on the satellite images alone this cannot be ascribed to the effect of the COVID-19 containment measures, because of the possible role of meteorological factors.

\subsection{Ground-Based Observations}

Satellite observations show that after the Spring Festival in 2020, the concentrations of $\mathrm{NO}_{2}$ and $\mathrm{SO}_{2}$ decreased in most of the central and eastern parts of China, with some regional differences. To further look at these, ground-based data for different cities were intercompared because of the expected differences between large cities, such as Beijing, Shanghai, Guangzhou, etc., from where many people leave to their families in other parts of the country and thus human activity will decrease, whereas in other areas, the temporarily increasing domestic activities may have the opposite effect. The satellite data shows such differences, but for column-integrated quantities rather than at the ground level and for monthly averages rather than daily. In 2020, strict control measures were enforced in Wuhan after the COVID-19 outbreak, leading to a complete lock-down of both the city and Hubei province, while also in the rest of China very severe measures were taken to avoid spreading of the COVID-19 virus. Therefore, the main focus of the ground-based AQ data analysis was Wuhan, for which a detailed overview of the data described in Section 3.1 is presented and discussed based on both monthly and daily averages. A comparison with other cities, 26 provincial capitals presented in Section 2, is made based on monthly averages.

Here, we included data for 2017-2020, initially to account for tendencies, such as the decreasing concentrations due to emission control policy. However, in many cases, this appeared not possible due to meteorological and other local influences that cannot be removed based on a period of 1 month over 3 years. Nevertheless, the comparison over several years appears useful to see the local fluctuations and effects of meteorological factors.

\subsubsection{Wuhan}

The concentrations of the four trace gases $\left(\mathrm{NO}_{2}, \mathrm{SO}_{2}, \mathrm{CO}\right.$, and $\left.\mathrm{O}_{3}\right), \mathrm{PM}_{2.5}$, and $\mathrm{PM}_{10}$ used in this study are daily averages representative for the whole city (Section 3.1). For each of the four years, these data were averaged over a period of 30 days before the Spring Festival, and over a period of 30 days after. The mean concentrations are presented in Figure 6 together with the standard deviations. The data show that for all species except $\mathrm{O}_{3}$, the concentrations in each of the four years are lower after the Spring Festival than before. For $\mathrm{NO}_{2}$, the concentrations decrease from year to year and a comparison between the 30-day periods before and after the Spring Festival during four years shows that the concentration in 2020 decreased substantially more than would be expected from the behavior in previous years, which could be an indication of the effect of the COVID-19 measures. The $\mathrm{SO}_{2}$ concentrations in Wuhan were low in all years, as is also clear from the satellite data. In each of the four years, a reduction is observed after the Spring Festival, but in 2020, the concentrations after the Spring Festival were only marginally lower than before. For the other species, there was no significant tendency in the mean concentrations before the Spring Festival. $\mathrm{PM}_{10}$ decreased slightly during the first three years and dropped substantially in 2020. However, after the Spring Festival, the $\mathrm{PM}_{10}$ concentrations dropped by a similar amount as in 2017-2019. This behavior is different from that of $\mathrm{PM}_{2.5}$ and may reflect the effect of coarse particles in $\mathrm{PM}_{10}$. In 2020 , the mean $\mathrm{PM}_{10}$ is not much larger than $\mathrm{PM}_{2.5}$ (less than 20\%) while in previous years the coarse particle fraction had a larger contribution. This could be an effect of reduced traffic resulting in less road dust in the air. CO is also somewhat smaller after the Spring Festival in each of the four years, but the difference varies from year to year and was larger in 2019 than in 2020. $\mathrm{O}_{3}$ is a more complicated case and will be discussed below. 


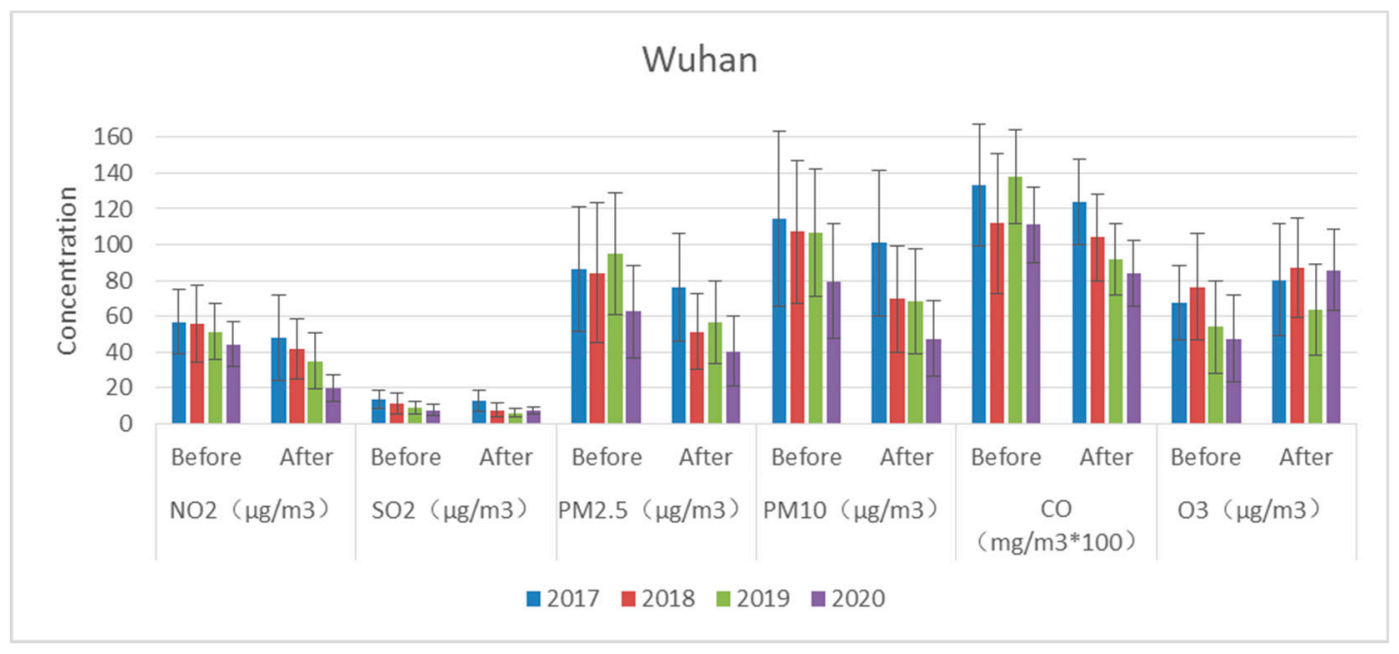

Figure 6. Mean and standard deviation for 30 days before and 30 days after the Spring Festivals in the years 2017-2020, for $\mathrm{NO}_{2}, \mathrm{SO}_{2}, \mathrm{PM}_{2.5}, \mathrm{PM}_{10}, \mathrm{CO}$, and $\mathrm{O}_{3}$ in Wuhan.

The daily mean concentrations of the various species contributing to the air quality in Wuhan are plotted in Figure 7 as time series from 30 days before the Spring Festival to 30 days after, for each of the four years 2017-2020. The time series are synchronized such that the Spring Festival dates coincide in the middle of the plot.

The $\mathrm{NO}_{2}$ concentrations show large variations in each of the four years, and in each year, they start to decrease a few days to more than a week before the Spring Festival to reach a minimum value of about $20 \mu \mathrm{g} \cdot \mathrm{m}^{-3}$ or less at about 2-3 days after the Spring Festival. In the next 10-12 days, the concentrations increased gradually by a factor of $2-3$ in a similar way in each of the years and after 2-3 weeks they reach levels similar to those before the Spring Festival. In 2020, the $\mathrm{NO}_{2}$ concentrations were initially also rising as in previous years but in contrast, after about 12 days, they dropped and remained low at about $20 \mu \mathrm{g} \cdot \mathrm{m}^{-3}$. With the lock-down of Wuhan on 23 January, two days before the Spring Festival, which was on 25 January, the clear deviation from other years becomes apparent at about 2 weeks after lock-down. The reasons for this long delay may be the holiday after the festival and the gradual return of people to their work place and start-up of factories and businesses, causing the initial increase, while it was only after the first week that the effect of the Hubei lock-down and measures country-wide influenced the economy and daily life and thus related emissions. Obviously, the concentrations are influenced by local weather conditions, which are reflected in the fluctuations in, and differences between, previous years. In summary, the $\mathrm{NO}_{2}$ time series in Figure 7 indicates a decrease in $\mathrm{NO}_{2}$ concentrations due to the Spring Festival effect from an average level of $40-80 \mu \mathrm{g} \cdot \mathrm{m}^{-3}$ to $20 \mu \mathrm{g} \cdot \mathrm{m}^{-3} \mathrm{or}$ less, i.e., a reduction by a factor of $2-4$, similar to that deduced from satellite observations. This factor is more than about $50 \%$ indicated by the $\mathrm{NO}_{2}$ concentration data in Figure 6 . However, note that Figure 6 shows 30-day averages, which before the Spring Festival include the decline in the 30-day period after the initial rise, whereas the factor of 3-4 reflects the reduction from an average level of $60-80 \mu \mathrm{g} \cdot \mathrm{m}^{-3}$ more than a week before the Spring Festival to the lowest values a few days after. The COVID-19 measures affect the $\mathrm{NO}_{2}$ concentrations only about 12 days after the Spring Festival, when in other years, the concentrations are up to "normal' levels but those in 2020 return to the lowest values of about $20 \mu \mathrm{g} \cdot \mathrm{m}^{-3}$.

The $\mathrm{SO}_{2}$ concentrations vary in a similar way as the $\mathrm{NO}_{2}$ concentrations for most of the time during the four years included in this study. The $\mathrm{SO}_{2}$ and $\mathrm{NO}_{2}$ concentrations trace each other, which may reflect the effect of weather conditions on the accumulation of the trace gases. However, in 2020, the $\mathrm{SO}_{2}$ concentrations were substantially lower than in previous years, during almost the whole 30-day period before the Spring Festival $\left(5-7 \mu \mathrm{g} \cdot \mathrm{m}^{-3}\right)$. After the Spring Festival, the $\mathrm{SO}_{2}$ concentrations 
behaved similarly to those of $\mathrm{NO}_{2}$, i.e., after an initial small increase they returned to lower values and remained between 5 and $10 \mu \mathrm{g} \cdot \mathrm{m}^{-3}$.
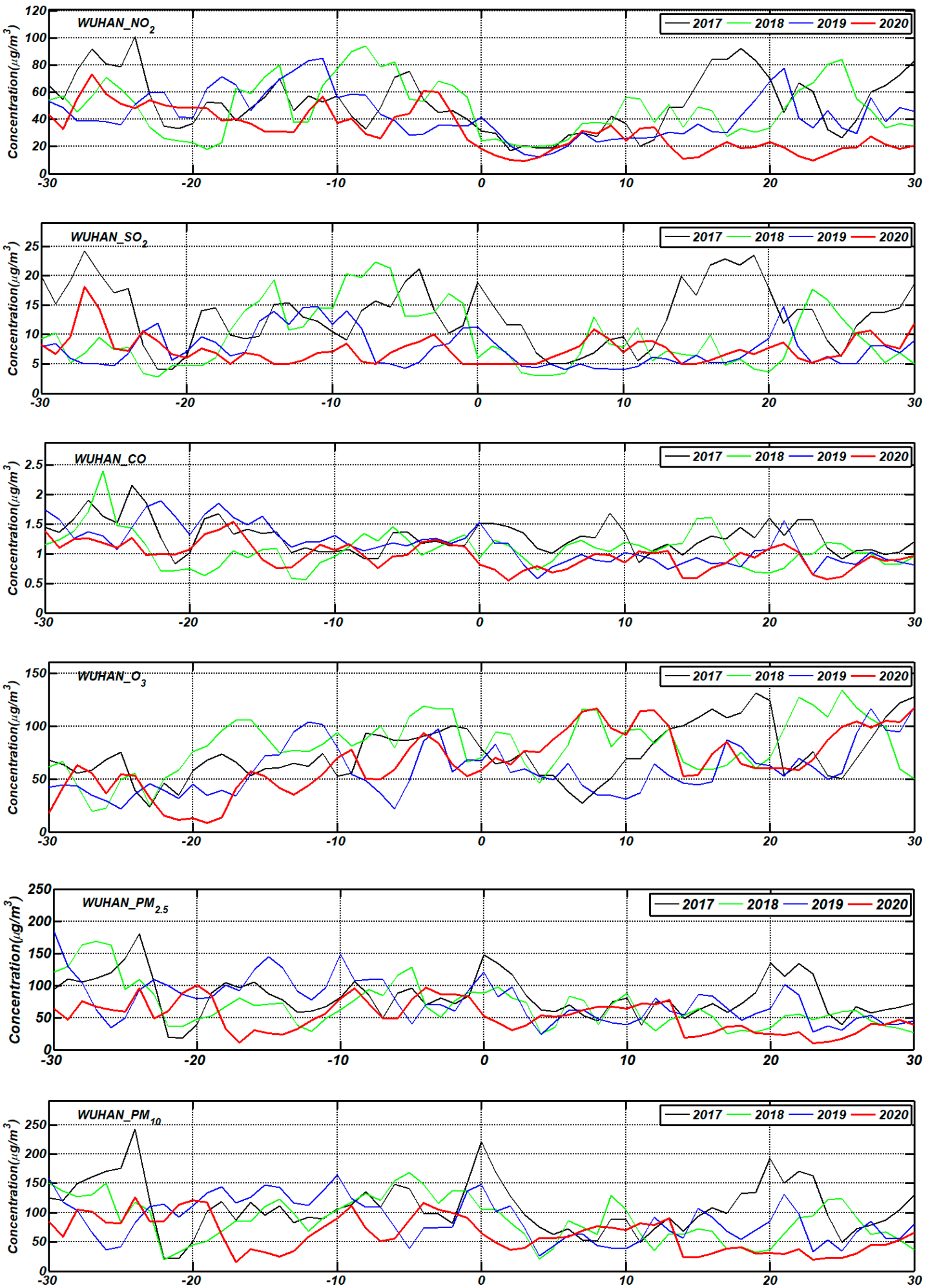

Figure 7. Time series of ground-based concentrations of $\mathrm{NO}_{2}, \mathrm{SO}_{2}, \mathrm{PM}_{2.5}, \mathrm{PM}_{10}, \mathrm{CO}$, and $\mathrm{O}_{3}$ measured in Wuhan during 2017-2020, from 30 days before to 30 days after the Spring Festival. 
$\mathrm{NO}_{2}$ and $\mathrm{SO}_{2}$ are aerosol precursors, but there are many other sources contributing to aerosol formation and direct emissions, which lead to the observed $\mathrm{PM}_{2.5}$ and $\mathrm{PM}_{10}$ concentrations. Therefore, the variation of the $\mathrm{PM}_{\mathrm{x}}$ (where $\mathrm{x}$ stands for either 2.5 or 10) concentrations may sometimes vary in a similar way as that of $\mathrm{NO}_{2}$ or $\mathrm{SO}_{2}$, with coincident peak values, but at other times they may be very different and not trace the gas concentrations. During the 2020 Spring Festival period the $\mathrm{PM}_{\mathrm{x}}$ concentrations behaved similarly to those of $\mathrm{NO}_{2}$, with strong variations which, for $\mathrm{PM}_{2.5}$, were on average between 50 and $100 \mu \mathrm{g} \cdot \mathrm{m}^{-3}$ before the Spring Festival, as in previous years. $\mathrm{PM}_{10}$ concentrations were similar but somewhat lower than in previous years, indicating a smaller fraction of coarse particles. PMx concentrations started to drop from about $100 \mu \mathrm{g} \cdot \mathrm{m}^{-3}$ a few days before the Spring Festival to $30-40 \mu \mathrm{g} \cdot \mathrm{m}^{-3}$ a few days after. This decrease was followed by a small but gradual increase during the next 11 days to about $75(90) \mu \mathrm{g} \cdot \mathrm{m}^{-3}$ for $\mathrm{PM}_{2.5}\left(\mathrm{PM}_{10}\right)$. Both $\mathrm{PM}_{2.5}$ and $\mathrm{PM}_{10}$ dropped to about $20 \mu \mathrm{g} \cdot \mathrm{m}^{-3}$ on 7 February, probably due to wash out by rain during the previous day; after 7 February the concentrations remained very low.

For $\mathrm{CO}$, the situation is different from that for $\mathrm{NO}_{2}, \mathrm{SO}_{2}$, and $\mathrm{PM}_{\mathrm{x}}$. $\mathrm{CO}$ concentrations before the Spring Festival vary in a similar way, i.e., they increase and decrease concomitantly with the other trace gases but with different amplitudes. Hence, the variations are likely due to meteorological influences, including transport. The concentrations decrease during the Spring Festival holiday period, but the onset of this decrease is different in all four years and also the relative decrease in the concentrations, from the Spring Festival to the day when the minimum occurs, varies between by $0.5-1 \mu \mathrm{g} \cdot \mathrm{m}^{-3}$. During the three first years, the minimum occurs on about the same day (4 days after Spring Festival), but in 2020, it occurs 2 days earlier. Furthermore, a sudden drop occurs on 7 February, similar to that for $\mathrm{PM}_{\mathrm{x}}$, but in contrast to $\mathrm{PM}_{\mathrm{x}}$, which remained low, $\mathrm{CO}$ concentrations recovered and, although on the low side, they were not much different than those in previous years.

The $\mathrm{O}_{3}$ concentrations are shown because of their importance for air quality. As expected, the behavior of $\mathrm{O}_{3}$ is different from that of the other species. Comparison with $\mathrm{NO}_{2}$ shows similar fluctuations due to meteorological influences, but at the same time, $\mathrm{O}_{3}$ is removed by $\mathrm{NO}_{\mathrm{x}}$ titration, i.e., a reduction in $\mathrm{NO}_{x}(\mathrm{NO})$ can contribute to an increase in $\mathrm{O}_{3}$ [53]. Although in previous years this effect is not easy to see, in 2020, the $\mathrm{O}_{3}$ concentrations are very high after day-zero.

\subsubsection{Comparison between Different Cities}

A comparison of the ratios of the averaged concentrations of $\mathrm{NO}_{2}$ and $\mathrm{O}_{3}$ after the Spring Festival to those before the Spring Festival for four years in 26 provincial capital cities is presented in Figure 8. Those for the other species included in this study $\left(\mathrm{SO}_{2}, \mathrm{PM}_{2.5}, \mathrm{PM}_{10}\right.$, and $\left.\mathrm{CO}\right)$ are presented in Figure $\mathrm{S} 5$. The cities (see the map in Figure 1 for their locations) are roughly ordered in a circle going from Taiyuan to the east to Harbin, then to the south to Fuzhou, then to the west to include cities in central and south China, and then back north.

In Wuhan, for which the daily variations were discussed in the previous section, the NO2 ratios gradually decrease in the first three years and then drop by about $30 \%$ in 2020 . In other cities, a reduction in NO2 concentrations after the Spring Festival in 2020 is also observed, but the amount varies between cities and also the behavior in previous years varies. The lowest ratios in 2020 are observed in Hangzhou and Chengdu with about $35 \%$ and a decrease with respect to 2019 of $60 \%-70 \%$. The highest ratio is observed in Lanzhou (60\%) and the difference with respect to 2019 is quite small (about 10\%). Keeping in mind the ordering of the cities, it appears that the ratio is relatively larger for those in the north and west than for those in central and south China. In other words, the reduction in air pollution in the north due to the lock-down is relatively smaller than in central and south China.

The $\mathrm{O}_{3}$ concentration ratios (after/before) are almost all larger than 1, with the exception of Guangzhou and Nanning. In almost all cities, the $\mathrm{O}_{3}$ ratios were highest in 2020, with the exception of Changchun and Guangzhou, or similar to the ratio in one of the previous years. It is likely these large values, indicating an increase of $\mathrm{O}_{3}$ after the Spring Festival, are due to $\mathrm{NO}_{\mathrm{x}}$ titration, which enhances the $\mathrm{O}_{3}$ concentrations when $\mathrm{NO}_{x}$ concentrations become smaller, as indicated above. 

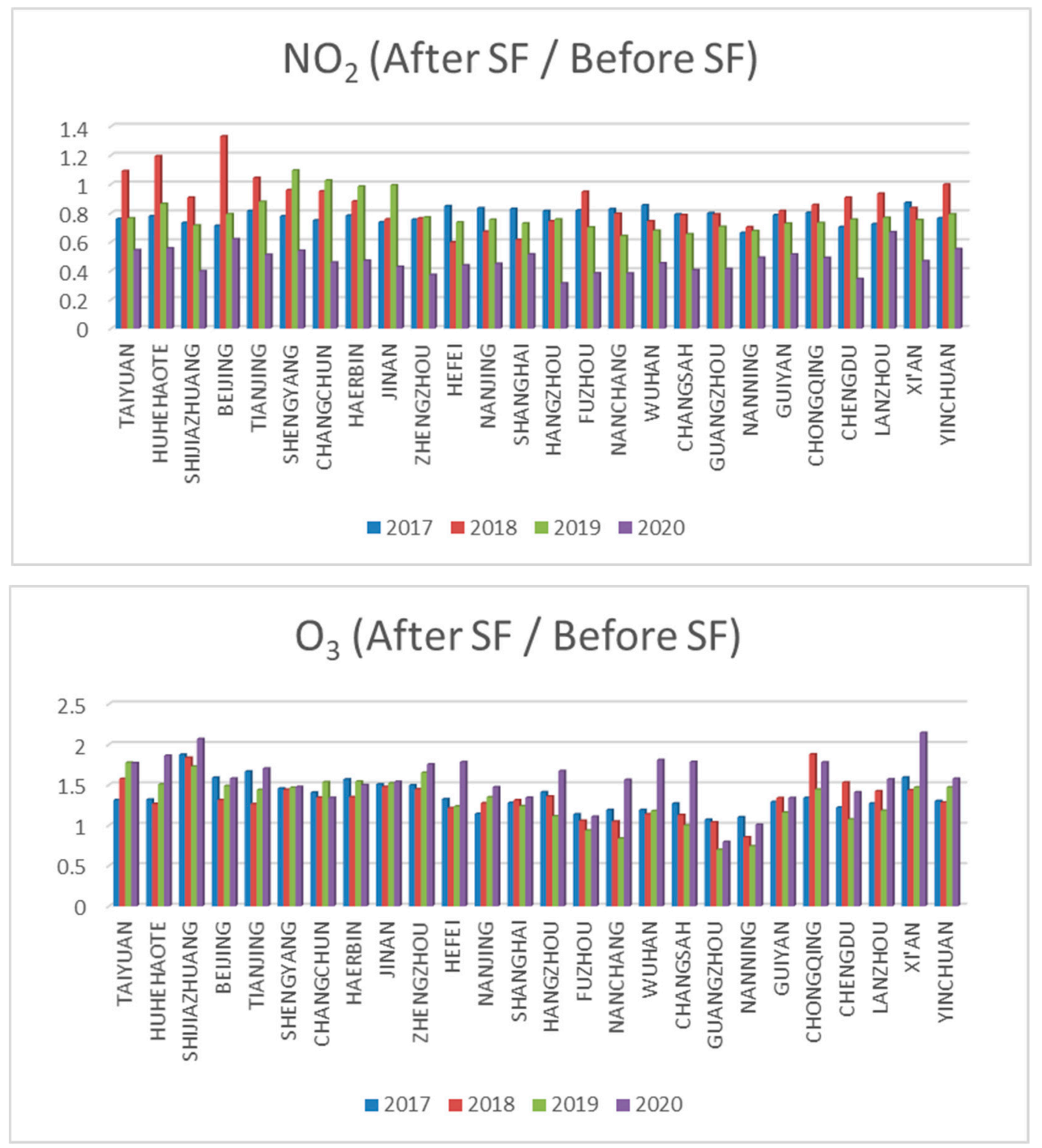

Figure 8. Ratio of the monthly averaged concentrations of $\mathrm{NO}_{2}$ and $\mathrm{O}_{3}$ after the Spring Festival to those before the Spring Festival, for each of 26 provincial capital cities for the years 2017-2020. The concentrations were averaged over a period of 30 days before and after Spring Festival. Note the different scales on the vertical axes.

The $\mathrm{PM}_{2.5}$ ratios (Figure S5a) are similar in all cities, apart from some cities in the north (see Supplementary Material for detail), varying between 0.5 and 1 over all four years. The 2020 lock-down did not seem to influence these, i.e., in 2020 the values are not lower than in previous years and for two cities, Nanning and Guiyang, the ratios are highest in 2020 (0.9 and 1, respectively).

For $\mathrm{PM}_{10}$ (Figure $\mathrm{S} 5 \mathrm{~b}$ ), the ratios vary between cities and years in a way similar to those of $\mathrm{PM}_{2.5}$, although the highest peak value of 3 observed in Beijing does not occur in the $\mathrm{PM}_{10}$ data set. This indicates that the high $\mathrm{PM}_{2.5}$ value occurred during a haze episode with a large abundance of fine particles.

For $\mathrm{SO}_{2}$ (Figure $\mathrm{S} 5 \mathrm{c}$ ), the ratios are less variable between the different years than for $\mathrm{NO}_{2}$, and also in 2020, the $\mathrm{SO}_{2}$ concentrations were not reduced as much after the Spring Festival as for $\mathrm{NO}_{2}$. Hence, the effect of the COVID-19 measures on $\mathrm{SO}_{2}$ is not easy to quantify. 
Additionally, for $\mathrm{CO}$, there is little variation between the various cities and no substantial decrease in 2020. Overall, the ratios were relatively high, larger than 0.6 and higher in the southern cities. The variations in specific years, for cities in the north and northeast, are discussed in the Supplementary Material [54-59].

\section{Discussion}

The analysis of the decrease of the aerosols and trace gas concentrations is based on satellite observations and time series of concentrations in major cities. However, although satellite- and ground-based instruments provide information on the same species, they use different techniques and measure different properties, which in addition may be influenced in different ways by, for instance, meteorological factors. When such factors cannot fully be accounted for, they contribute to uncertainties in the estimated effects. Taking them into account in the required detail is beyond the scope of the current study and the following discussion is qualitative.

Satellite observations provide the spatial variations of concentrations for different periods. Ratio plots were used to study the spatial variations of the decrease of the concentrations due to reduced activities during the Spring Festival holidays, extended and augmented in 2020 due to the measures to avoid spreading of the COVID-19 virus. The separate effects of the Spring Festival and the COVID-19 containment measures were estimated as described in Section 4.1. In these estimates, 30-day periods were used in an attempt to average variations in trace gas and aerosol concentrations due to meteorological influences, assuming that emissions did not change except due to the Spring Festival holidays. Obviously, a period of 30 days is not enough to obtain a representative estimate, in particular in regions with variable meteorological conditions, which may be conducive of the accumulation of aerosols and trace gases and thus the formation of haze (e.g., [60,61]), while in other conditions, the air may be very clear. Because the meteorological conditions during the periods compared in this study were not the same, the method introduces an uncertainty in the resulting estimates. An alternative to avoiding such sources of uncertainty would be the use of a chemical transport model (CTM), which, however, would introduce other uncertainties (e.g., [62]).

The effect of meteorological variations is clearly visible in the variations of the ground-based concentrations in Figure 7 and Figure S5. For instance, the co-variation of $\mathrm{NO}_{2}$ and $\mathrm{SO}_{2}$ and to some extent $\mathrm{PM}_{2.5}$ reflects meteorological influences, with deviations of $\mathrm{PM}_{2.5}$ from that of the gaseous species because of additional effects, such as hygroscopic growth effects due to relative humidity (RH) variations or the formation of new particles.

Another uncertainty in the estimates is the steady decline of the concentrations during the last decade, as concluded from satellite observations. This has been accounted for in satellite data by relating the 2020 concentrations and their reduction after the Spring Festival to those in 2019 (Equation (2)). The Spring Festival date changes from year to year, which also induces some, probably small, uncertainty because of the seasonal variation of air pollutants, as clearly demonstrated for $\mathrm{NO}_{2}$ in, e.g., [63] for ground-based concentrations or in [26], where the month-to-month differences in the TROPOMI tropospheric $\mathrm{NO}_{2}$ VCDs were clearly illustrated. For AOD, the seasonal variations were illustrated with ATSR (Advanced Along-Track Radiometer) and MODIS data by, e.g., [3,4], with high $\mathrm{AOD}$ in the summer and low in the winter. In contrast, $\mathrm{PM}_{2.5}$ concentrations are high in the winter and low in the summer (e.g., [64]). The difference between the seasonal behavior of AOD and $\mathrm{PM}_{2.5}$ is due to meteorological influences.

The time series in Figure 7 and Figure S5 show daily averaged in situ concentrations. In Figure 9, collocated TROPOMI observations of tropospheric $\mathrm{NO}_{2}$ VCDs, during the TROPOMI daily overpass early in the afternoon, are shown together with daily-averaged $\mathrm{NO}_{2}$ surface concentrations in 2019 and 2020. Figure 9 shows the differences in both the values and the temporal variations of the different measures for the $\mathrm{NO}_{2}$ concentration. In 2020, the VCDs and ground-based concentrations vary with time in a similar fashion, but in 2019 , their temporal behavior is different. VCDs are concentrations integrated over the whole column, representative for the slant path observation in a pixel with an 
area of $7 \times 3.5 \mathrm{~km}^{2}$ sub-nadir, and at a certain time. Ground-based in situ data are obtained from point measurements, in this study averaged over $24 \mathrm{~h}$, during which diurnal changes occur, and all point measurements in each city are averaged to reduce local gradients. The relation between the satellite VCD and ground-based in situ observations depends on meteorological conditions and for aerosols also on the chemical composition. This relation requires knowledge on the vertical variation of the concentrations, which is usually evaluated using a model approach. For instance, [63] showed the variability of $\mathrm{NO}_{2}$ vertical profiles in the troposphere between different locations in China for each of the four seasons and the differences between the annual variations of ground-based $\mathrm{NO}_{2}$ concentrations obtained using different methods. Another such comparison is made for several models in [62]. For aerosols, this comparison is even more complicated due to changes in aerosol physical and chemical properties in different meteorological conditions [65], as well as the different aerosol properties measured by satellite- and ground-based instruments. The in situ measurement relevant for AQ applications is the mass of particulate matter, $\mathrm{PM}_{2.5}$, which is measured by sampling particles with in situ aerodynamic diameters of $2.5 \mu \mathrm{m}$ (i.e., in equilibrium with ambient $\mathrm{RH}$ ), which then is brought into a low RH environment in which aerosol water evaporates before the mass is determined. Satellites measure the AOD, which is the column-integrated aerosol extinction, i.e., an optical property of aerosol particles, which depends on the aerosol composition and size distribution, which in turn changes with ambient $\mathrm{RH}$. The AOD/PM 2.5 relationship can be evaluated using statistical or physical methods or using a variety of CTMs [7,47-49]. It is noted that the AOD/PM 2.5 relation varies across China e.g., [49] and no relation fits all purposes.
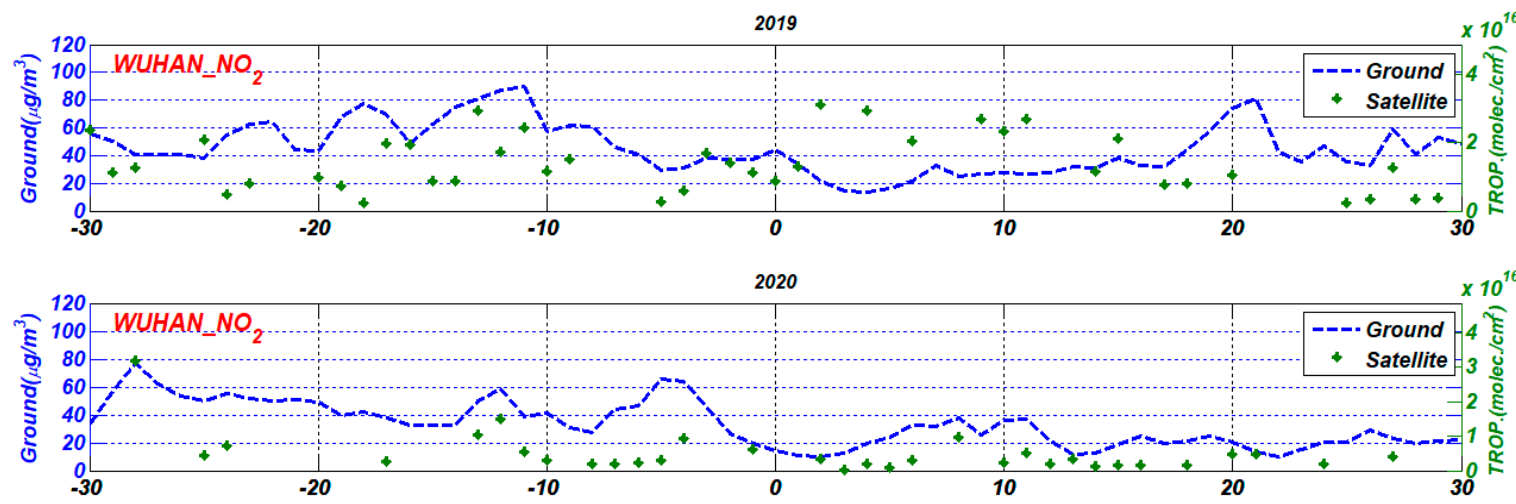

Figure 9. As Figure 6, for $\mathrm{NO}_{2}$ concentrations in 2019 and 2020 (broken lines) and the collocated daily TROPOMI $\mathrm{NO}_{2}$ tropospheric VCDs (crosses).

A further uncertainty in the estimates of the effect of COVID-19 containment measures on the $\mathrm{NO}_{2}$ and $\mathrm{SO}_{2}$ concentrations may be the sensitivity of the TROPOMI instrument. TROPOMI has limited sensitivity to $\mathrm{SO}_{2}$ as discussed in detail by [66], which may explain the speckle in the $\mathrm{SO}_{2}$ VCD figures (Figure S3). As regards $\mathrm{NO}_{2}$, comparison with ground-based reference data shows that TROPOMI tropospheric VCD has a negative bias of 30\% (http://mpc-vdaf.TROPOMI.eu/, last access: 6 April 2020), which implies that in an absolute sense, the high $\mathrm{NO}_{2}$ VCDs are underestimated by an amount that is larger than that for low $\mathrm{NO}_{2}$ VCDs. Hence, the ratio of the low concentrations after the Spring Festival to the higher concentrations before the Spring Festival may be underestimated due to the larger absolute measurement error before the Spring Festival.

The trace gas and aerosol concentrations observed from satellite observations over China show a steady decline [2,3]. In contrast, the local in situ observations during the last four years in Figure 6 do not show such behavior for all species. It is noted here that the locally representative ground-based measurements cannot be directly compared with satellite-derived trends estimated from columns on a provincial scale [2] or larger areas of $1^{\circ} \times 1^{\circ}$ [3] in which contributions from many sources are dispersed. 
Ground-based observations in Wuhan were discussed in detail in Section 4.2.1, where the Spring Festival has a clear effect on the concentrations of a reduction of the concentrations of $\mathrm{NO}_{2}, \mathrm{SO}_{2}, \mathrm{PM}_{10}$, and $\mathrm{PM}_{2.5}$ but not on $\mathrm{CO} . \mathrm{O}_{3}$ concentrations actually increased. Similar observations were presented by [15] for monthly averages, which shows a very strong decline from January to February 2014 for $\mathrm{NO}_{2}, \mathrm{SO}_{2}, \mathrm{PM}_{10}, \mathrm{PM}_{2.5}$, and also CO. Their measurements actually started in March 2013 and all concentrations declined until July, after which they increased to the winter peak in December. Hence, an increase in the concentrations of these components would not be expected. However, as Figure 7 and Figure S5 show, in preceding years 2017-2019, the concentrations were back to levels similar to those before the Spring Festival in 2020 at about 2 weeks after day-zero. In 2020, this did not happen although an initial increase is evident, in spite of the lockdown of Wuhan and many other cities in Hubei soon after. The initial rise may therefore reflect the transport of pollution from sources to the north and south of Wuhan [15] or long-range transport of desert dust [67]. To further investigate the recovery when COVID-19 measures were gradually weakened across China, longer time series were plotted for the 26 provincial capitals (not shown here) and the effects varied between them. Obviously, in Wuhan, all concentrations remained low during the lockdown. In some cities, indeed, a small increase was observed in the second month (e.g., Xi'an, Chongqing, Fuzhou), and not in others (e.g., Beijing).

\section{Conclusions}

The results presented in this paper clearly show the effect of measures inflicted to contain the COVID-19 virus in China in the winter of 2020 on the concentrations of trace gases $\left(\mathrm{NO}_{2}, \mathrm{SO}_{2}, \mathrm{CO}\right.$, and $\left.\mathrm{O}_{3}\right)$ and aerosols $\left(\mathrm{PM}_{2.5}\right.$ and $\left.\mathrm{PM}_{10}\right)$. These effects extended and augmented the usual Spring Festival effect on air quality and satellite images showed a very strong decrease in the concentrations. The effects of the COVID-19 measures were separated from the Spring Festival effect as described in Section 4.1. The results show a large reduction of $\mathrm{NO}_{2}$ during the Spring Festival, up to $80 \%$ in some regions. The further reduction due to the COVID-19 containment measures was estimated to be $50 \%-60 \%$ over the NCP and up to about $70 \%$ in some other areas, and lower elsewhere. Estimates for $\mathrm{SO}_{2}$ are difficult to make due to the limited sensitivity of TROPOMI to $\mathrm{SO}_{2}$ [66], which also reflects the successful reduction of $\mathrm{SO}_{2}$ concentrations over China since 2007 [2]. Accurate estimates of the reduction of aerosols, $\mathrm{PM}_{2.5}$ and $\mathrm{PM}_{10}$, or $\mathrm{CO}$ are difficult, due to the longer atmospheric lifetime of especially $\mathrm{CO}$ and the complex behavior of aerosols.

Ground-based in situ data in Wuhan do show the declining concentrations of $\mathrm{NO}_{2}, \mathrm{SO}_{2}, \mathrm{CO}$, $\mathrm{PM}_{2.5}$, and $\mathrm{PM}_{10}$, from a few days before the Spring Festival until about 2 weeks after, in 2017-2019. This behavior was initially also observed in 2020, but in contrast to earlier years, after 2 weeks, the concentrations of $\mathrm{NO}_{2}, \mathrm{SO}_{2}, \mathrm{PM}_{2.5}$, and $\mathrm{PM}_{10}$ remained low, which is ascribed to the effect of the COVID-19 measures. $\mathrm{CO}$ concentrations were less affected and increased after 2 weeks as in earlier years. Quantitatively, the $\mathrm{NO}_{2}$ concentrations decreased from an average level of $40-80 \mu \mathrm{g} \cdot \mathrm{m}^{-3}$ to $20 \mu \mathrm{g} \cdot \mathrm{m}^{-3}$, i.e., a reduction by a factor of $2-4$. PMx dropped initially from about $100 \mu \mathrm{g} \cdot \mathrm{m}^{-3}$ to $35 \mu \mathrm{g} \cdot \mathrm{m}^{-3}$, and after 2 weeks to about $20 \mu \mathrm{g} \cdot \mathrm{m}^{-3}$, i.e., a total reduction by a factor of 3-5. Assuming that in a "business as usual" scenario, i.e., with no COVID-19 outbreak when life would have taken its normal course, the concentrations would have returned to their normal levels, the COVID-19 measures resulted in a reduction by a factor $2-4$ of the $\mathrm{NO}_{2}$ concentrations, in line with the estimates from the satellite observations, and a factor of 3-5 for PMx. It is noted that the satellite observations did not provide an acceptable estimate for the COVID-19 effect on the aerosol concentrations (with AOD as proxy).

These numbers show a good agreement between estimates derived from satellite- and ground-based measurements but also provide an indication of problems in this kind of comparison. Possible uncertainties are caused by both technical/observation problems and physical phenomena complicating the interpretation of the observed phenomena. Examples were discussed in Section 5. 
The satellite-based estimates presented are based on data averaged over 30 days. However, as Figure 7 shows, in preceding years, the concentrations were back to levels similar to those before the Spring Festival about 2 weeks after day-zero. In 2020, this did not happen and that is the reason why the satellite images show so much lower concentrations after the Spring Festival in 2020 than in 2019: In 2019, the 30-day period included both the Spring Festival reduction and the recovery when people returned from their holidays and normal life was resumed. Hence, the Spring Festival effect based on the 30-day satellite observations is an underestimate and hence the COVID-19 effect an overestimate. For more reliable estimates, shorter periods of 2 weeks or less should be used.

In terms of air quality, the reduction of $\mathrm{NO}_{2}, \mathrm{SO}_{2}$, and $\mathrm{PM}_{2.5}$ concentrations was good news, except that the $\mathrm{O}_{3}$ concentrations increased, probably as a result of the lower $\mathrm{NO}_{x}$ concentrations. This was not only observed in Wuhan but also in the 26 provincial capital cities included in this study. These studies were made on 30-day averages of concentrations measured at several stations in each city, and averaged per city for better representativeness. In the second month after the 2020 Spring Festival, the ground-based observations showed a small increase of the concentrations in some cities, but in most cities, they did remain low until the end of the current study period on 26 March.

This study was a first attempt to estimate the separate effects of the Spring Festival and the COVID-19 containment measures. A more thorough estimate would take into account other effects, e.g., meteorological effects through the use of chemical transport models in which emissions would be kept at their original level and concentration changes are only caused by changes in the actual emissions due to the actual event. Top-down emission estimates using satellite data could provide detailed information on the actual changes in emissions as opposed to emission inventories, e.g., [68]. Another interesting study will be the recovery of the concentrations when the lock-down is gradually released and the effect of different activities on the concentrations can be monitored.

Supplementary Materials: The following are available online at http://www.mdpi.com/2072-4292/12/10/1613/s1, Figure S1: Map of China, including provinces, municipalities (Beijing Tianjin Shanghai and Chongqing), autonomous regions (Ningxia, Guangxi, Xizang, Xinjiang and Inner Mongolia) and special administrative regions (Hong Kong and Macau)., Figure S2: Ratio of $\mathrm{NO}_{2}$ tropospheric VCDs., Figure $\mathrm{S}_{\text {: }} \mathrm{SO}_{2}$ vertical column density averaged over 30 days before and after the Spring Festival in 2019 and 2020., Figure S4: Same as Figure S3, but for CO; Figure e has been added to show the effect on CO VCDs in the second month after the 2020 Spring Festival; Figure $\mathrm{f}$ is CO VCD difference map, showing the CO VCDs in month2 minus those in month1 after the 2020 Spring Festival., Figure S5: Ratio of the averaged concentrations of $\mathrm{PM}_{2.5}, \mathrm{PM}_{10}, \mathrm{SO}_{2}$ and $\mathrm{CO}$ after the Spring Festival to those before the Spring Festival, for each of 26 provincial capital cities for the years 2017-2020. The concentrations were averaged over a period of 30 days before and after Spring Festival. References $[44,45,54-59]$ are cited in the Supplementary Materials.

Author Contributions: C.F. and Y.L. were involved in the research design. C.F., Y.L., A.E., and M.A. analysis of the data. C.F., Y.L. and G.d.L. finalized the paper. J.G. and Z.L. gave useful comments which improved the paper. All authors have read and agreed to the published version of the manuscript.

Funding: This research was funded by the Ministry of Science and Technology (MOST) of China, grant number 2016YFC0200500, the National Natural Science Foundation of China, grant number 41925019 and 41590855, and the Strategic Priority Research Program of the Chinese Academy of Sciences, grant number XDA19080303.

Acknowledgments: The authors acknowledge the NASA Earth Science Division for the free use of tropospheric $\mathrm{NO}_{2}, \mathrm{SO}_{2}$ and $\mathrm{CO}$ products from the TROPOMI (Sentinel-5P) sensor. We acknowledge the free access to the ground-based data from Ministry of Environmental Protection of the People's Republic of China. We thank their team for the calibration and maintenance of the instrumentation. We also want to express our sincere gratitude to the anonymous reviews and editors for their comments which contributed to the improvement of the paper.

Conflicts of Interest: The authors declare no conflict of interest.

\section{References}

1. China's per Capita GDP Makes a Breakthrough. Available online: https://www.shine.cn/biz/economy/ 2001170057/ (accessed on 17 January 2020).

2. $\quad$ van der, A.R.; Mijling, B.; Ding, J.; Koukouli, M.; Liu, F.; Li, Q.; Mao, H.; Theys, N. Cleaning up the air: Effectiveness of air quality policy for SO2 and NOx emissions in China. Atmos. Chem. Phys. 2017,17, 1775-1789. [CrossRef] 
3. Sogacheva, L.; Rodriguez, E.; Kolmonen, P.; Virtanen, T.; Saponaro, G.; de Leeuw, G.; Georgoulias, A.; Alexandri, G.; Kourtidis, K.; van der, A.R. Spatial and seasonal variations of aerosols over China from two decades of multi-satellite observations-Part 2: AOD time series for 1995-2017 combined from ATSR ADV and MODIS C6.1 and AOD tendency estimations. Atmos. Chem. Phys. 2018, 18, 16631-16652. [CrossRef]

4. de Leeuw, G.; Sogacheva, L.; Rodriguez, E.; Kourtidis, K.; Georgoulias, A.; Alexandri, G.; Amiridis, V.; Proestakis, E.; Marinou, E.; Xue, Y.; et al. Two decades of satellite observations of AOD over mainland China using ATSR-2, AATSR and MODIS/Terra: Data set evaluation and large-scale patterns. Atmos. Chem. Phys. 2018, 18, 1573-1592. [CrossRef]

5. Sogacheva, L.; de Leeuw, G.; Rodriguez, E.; Kolmonen, P.; Georgoulias, A.; Alexandri, G.; Kourtidis, K.; Proestakis, E.; Marinou, E.; Amiridis, V.; et al. Spatial and seasonal variations of aerosols over China from two decades of multi-satellite observations-Part 1: ATSR (1995-2011) and MODIS C6.1 (2000-2017). Atmos. Chem. Phys. 2018, 18, 11389-11407. [CrossRef]

6. Fontes, T.; Li, P.; Barros, N.; Zhao, P. Trends of PM2.5 concentrations in China: A long term approach. J. Environ. Manag. 2017, 196, 719-732. [CrossRef]

7. Zhai, S.; Jacob, D.; Wang, X.; Shen, L.; Ke, L.; Zhang, Y.; Gui, K.; Zhao, T.; Liao, H. Fine particulate matter (PM2.5) trends in China, 2013-2018: Separating contributions from anthropogenic emissions and meteorology. Atmos. Chem. Phys. 2019, 19, 11031-11041. [CrossRef]

8. Silver, B.; Reddington, C.; Arnold, S.; Spracklen, D. Substantial changes in air pollution across China during 2015 to 2017. Environ. Res. Lett. 2018, 13. [CrossRef]

9. Guo, H.; Gu, X.; Ma, G.; Shi, S.; Wang, W.; Zuo, X.; Zhang, X. Spatial and temporal variations of air quality and six air pollutants in China during 2015-2017. Sci. Rep. 2019, 9, 15201. [CrossRef]

10. Okuda, T.; Matsuura, S.; Yamaguchi, D.; Umemura, T.; Hanada, E.; Orihara, H.; Tanaka, S.; He, K.; Ma, Y.; Cheng, Y.; et al. The impact of the pollution control measures for the 2008 Beijing Olympic Games on the chemical composition of aerosols. Atmos. Environ. 2011, 45, 2789-2794. [CrossRef]

11. Xu, H.M.; Tao, J.; Ho, S.S.H.; Ho, K.F.; Cao, J.J.; Li, N.; Chow, J.C.; Wang, G.H.; Han, Y.M.; Zhang, R.J.; et al. Characteristics of fine particulate non-polar organic compounds in Guangzhou during the 16th Asian Games: Effectiveness of air pollution controls. Atmos. Environ. 2013, 76, 94-101. [CrossRef]

12. Ding, J.; van der A., R.; Mijling, B.; Levelt, P.; Hao, N. NOx emission estimates during the 2014 Youth Olympic Games in Nanjing. Atmos. Chem. Phys. Discuss. 2015, 15, 6337-6372. [CrossRef]

13. Chen, C.; Sun, Y.L.; Xu, W.Q.; Du, W.; Zhou, L.B.; Han, T.T.; Wang, Q.Q.; Fu, P.Q.; Wang, Z.F.; Gao, Z.Q.; et al. Characteristics and sources of submicron aerosols above the urban canopy (260 $\mathrm{m}$ ) in Beijing, China, during the 2014 APEC summit. Atmos. Chem. Phys. 2015, 15, 12879-12895. [CrossRef]

14. Zhao, J.; Du, W.; Zhang, Y.J.; Wang, Q.Q.; Chen, C.; Xu, W.Q.; Han, T.T.; Wang, Y.Y.; Fu, P.Q.; Wang, Z.F.; et al. Insights into aerosol chemistry during the 2015 China Victory Day parade: Results from simultaneous measurements at ground level and $260 \mathrm{~m}$ in Beijing. Atmos. Chem. Phys. 2017, 17, 3215-3232. [CrossRef]

15. Wang, C.; Huang, X.-F.; Zhu, Q.; Cao, L.-M.; Zhang, B.; He, L.-Y. Differentiating local and regional sources of Chinese urban air pollution based on the effect of the Spring Festival. Atmos. Chem. Phys. 2017, 17, 9103-9114. [CrossRef]

16. Yao, L.; Wang, D.F.; Fu, Q.Y.; Qiao, L.P.; Wang, H.L.; Li, L.; Sun, W.W.; Li, Q.; Wang, L.; Yang, X.; et al. The effects of firework regulation on air quality and public health during the Chinese Spring Festival from 2013 to 2017 in a Chinese megacity. Environ. Int. 2019, 126, 96-106. [CrossRef]

17. Feng, J.L.; Yu, H.; Su, X.F.; Liu, S.H.; Li, Y.; Pan, Y.P.; Sun, J.H. Chemical composition and source apportionment of PM2.5 during Chinese Spring Festival at Xinxiang, a heavily polluted city in North China: Fireworks and health risks. Atmos. Res. 2016, 182, 176-188. [CrossRef]

18. Tang, M.; Ji, D.; Gao, W.-K.; Yu, Z.-W.; Chen, K.; Cao, W. Characteristics of air quality in Tianjin during the Spring Festival period of 2015. Atmos. Ocean. Sci. Lett. 2016, 9, 15-21. [CrossRef]

19. Simmons, G.; Reeves, J.D.; Rennekamp, A.J.; Amberg, S.M.; Piefer, A.J.; Bates, P. Characterization of severe acute respiratory syndrome-associated coronavirus (SARS-CoV) spike glycoprotein-mediated viral entry. Proc. Natl. Acad. Sci. USA 2004, 101, 4240-4245. [CrossRef]

20. de Groot, R.J.; Baker, S.C.; Baric, R.S.; Brown, C.S.; Drosten, C.; Enjuanes, L.; Fouchier, R.A.M.; Galiano, M.; Gorbalenya, A.E.; Memish, Z.A.; et al. Middle East Respiratory Syndrome Coronavirus (MERS-CoV): Announcement of the Coronavirus Study Group. J. Virol. 2013, 87, 7790-7792. [CrossRef] 
21. Airborne Nitrogen Dioxide Plummets Over China. Available online: https:/earthobservatory.nasa.gov/ images/146362/airborne-nitrogen-dioxide-plummets-over-china (accessed on 2 March 2020).

22. Watch the Footprint of Coronavirus Spread Across Countries. Available online: https://www.nytimes.com/ interactive/2020/climate/coronavirus-pollution.html (accessed on 17 March 2020).

23. COVID-19: Nitrogen Dioxide Over China. Available online: https://earth.esa.int/web/guest/news/-/article/ covid-19-nitrogen-dioxide-over-china (accessed on 19 March 2020).

24. Clean Air above Italy and China. Available online: https://www.delta.tudelft.nl/article/cleaner-air-aboveitaly-and-china (accessed on 19 March 2020).

25. Hu, H.Y. The Distribution of Population in China, With Statistics and Maps. J. Geogr. Sci. 1935, 2, 191-192.

26. Zheng, Z.; Yang, Z.; Wu, Z.; Marinello, F. Spatial Variation of NO2 and Its Impact Factors in China: An Application of Sentinel-5P Products. Remote Sens. 2019, 11, 1939. [CrossRef]

27. Liu, Z.R.; Gao, W.K.; Yu, Y.C.; Hu, B.; Xin, J.Y.; Sun, Y.; Wang, L.L.; Wang, G.H.; Bi, X.H.; Zhang, G.H.; et al. Characteristics of PM2.5 mass concentrations and chemical species in urban and background areas of China: Emerging results from the CARE-China network. Atmos. Chem. Phys. 2018, 18, 8849-8871. [CrossRef]

28. Ambient Air Quality Standards (GB3095-2012); Ministry of Environmental Protection of the People's Republic of China (MEE): Beijing, China, 2012.

29. Xue, Y.; Li, Y.; Guang, J.; Tugui, A.; She, L.; Qin, K.; Fan, C.; Che, Y.; Xie, Y.; Wen, Y.; et al. Hourly PM2.5 Estimation over Central and Eastern China Based on Himawari-8 Data. Remote Sens. 2020, 12, 855. [CrossRef]

30. Fan, H.; Zhao, C.F.; Yang, Y.K. A comprehensive analysis of the spatio-temporal variation of urban air pollution in China during 2014-2018. Atmos. Environ. 2020, 220, 117066. [CrossRef]

31. Lunar Phase. Available online: https://en.wikipedia.org/wiki/Lunar_phase (accessed on 12 May 2020).

32. Coronavirus Detected in Wuhan in Late December: China. Available online: https:/economictimes. indiatimes.com/news/international/world-news/coronavirus-detected-in-wuhan-in-late-december-china/ articleshow/75028126.cms?utm_source=contentofinterest\&utm_medium=text\&utm_campaign=cppst (accessed on 7 April 2020).

33. Gorelick, N.; Hancher, M.; Dixon, M.; Ilyushchenko, S.; Thau, D.; Moore, R. Google Earth Engine: Planetary-scale geospatial analysis for everyone. Remote Sens. Environ. 2017, 202, 18-27. [CrossRef]

34. Kneissl, T.; van Gasselt, S.; Neukum, G. Map-projection-independent crater size-frequency determination in GIS environments-New software tool for ArcGIS. Planet. Space Sci. 2011, 59, 1243-1254. [CrossRef]

35. Veefkind, J.P.; Aben, I.; McMullan, K.; Förster, H.; de Vries, J.; Otter, G.; Claas, J.; Eskes, H.J.; de Haan, J.F.; Kleipool, Q.; et al. TROPOMI on the ESA Sentinel-5 Precursor: A GMES mission for global observations of the atmospheric composition for climate, air quality and ozone layer applications. Remote Sens. Environ. 2012, 120, 70-83. [CrossRef]

36. Salomonson, V.; Magner, T.; Barnes, W.; Montgomery, H.; Ostrow, H. Moderate Resolution Imaging Spectrometer A Progress Report (April 1989). In Proceedings of the IGARSS '89 and Canadian Symposium on Remote Sensing, 12th, Vancouver, BC, Canada, 10-14 July 1989; pp. 2917-2921.

37. Lyapustin, A.; Wang, Y.; Laszlo, I.; Kahn, R.; Korkin, S.; Remer, L.; Levy, R.; Reid, J.S. Multiangle implementation of atmospheric correction (MAIAC): 2. Aerosol algorithm. J. Geophys. Res.-Atmos. 2011, 116. [CrossRef]

38. Lyapustin, A.; Wang, Y.J.; Korkin, S.; Huang, D. MODIS Collection 6 MAIAC algorithm. Atmos. Meas. Tech. 2018, 11, 5741-5765. [CrossRef]

39. Mhawish, A.; Banerjee, T.; Sorek-Hamer, M.; Lyapustin, A.; Broday, D.M.; Chatfield, R. Comparison and evaluation of MODIS Multi-angle Implementation of Atmospheric Correction (MAIAC) aerosol product over South Asia. Remote Sens. Environ. 2019, 224, 12-28. [CrossRef]

40. She, L.; Zhang, H.; Wang, W.; Wang, Y.; Shi, Y. Evaluation of the Multi-Angle Implementation of Atmospheric Correction (MAIAC) Aerosol Algorithm for Himawari-8 Data. Remote Sens. 2019, 11, 2771. [CrossRef]

41. Zhang, Z.Y.; Wu, W.L.; Fan, M.; Wei, J.; Tan, Y.H.; Wang, Q. Evaluation of MAIAC aerosol retrievals over China. Atmos. Environ. 2019, 202, 8-16. [CrossRef]

42. Li, Y.; Xue, Y.; Guang, J.; She, L.; Fan, C.; Chen, G. Ground-Level PM2.5 Concentration Estimation from Satellite Data in the Beijing Area Using a Specific Particle Swarm Extinction Mass Conversion Algorithm. Remote Sens. 2018, 10, 1906. [CrossRef] 
43. Liang, F.C.; Xiao, Q.Y.; Wang, Y.J.; Lyapustin, A.; Li, G.X.; Gu, D.F.; Pan, X.C.; Liu, Y. MAIAC-based long-term spatiotemporal trends of PM2.5 in Beijing, China. Sci. Total Environ. 2018, 616, 1589-1598. [CrossRef] [PubMed]

44. Krotkov, N.A.; McLinden, C.A.; Li, C.; Lamsal, L.N.; Celarier, E.A.; Marchenko, S.V.; Swartz, W.H.; Bucsela, E.J.; Joiner, J.; Duncan, B.N.; et al. Aura OMI observations of regional SO2 and NO2 pollution changes from 2005 to 2015. Atmos. Chem. Phys. 2016, 16, 4605-4629. [CrossRef]

45. Zhao, Y.; Nielsen, C.P.; McElroy, M.B.; Zhang, L.; Zhang, J. CO emissions in China: Uncertainties and implications of improved energy efficiency and emission control. Atmos. Environ. 2012, 49, 103-113. [CrossRef]

46. Schneising, O.; Buchwitz, M.; Reuter, M.; Bovensmann, H.; Burrows, J.; Borsdorff, T.; Deutscher, N.; Feist, D.; Griffith, D.; Hase, F.; et al. A scientific algorithm to simultaneously retrieve carbon monoxide and methane from TROPOMI onboard Sentinel-5 Precursor. Atmos. Meas. Tech. 2019, 12, 6771-6802. [CrossRef]

47. Zhang, Y.; Li, Z. Remote sensing of atmospheric fine particulate matter (PM2.5) mass concentration near the ground from satellite observation. Remote Sens. Environ. 2015, 160, 252-262. [CrossRef]

48. Zhang, K.N.; de Leeuw, G.; Yang, Z.Q.; Chen, X.F.; Su, X.L.; Jiao, J.S. Estimating Spatio-Temporal Variations of PM2.5 Concentrations Using VIIRS-Derived AOD in the Guanzhong Basin, China. Remote Sens. 2019, 11, 2679. [CrossRef]

49. Xin, J.; Gong, C.; Liu, Z.; Cong, Z.; Gao, W.; Tao, S.; Pan, Y.; Sun, Y.; Ji, D.; Wang, L.; et al. The observation-based relationships between PM 2.5 and AOD over China: The functions of PM2.5 \& AOD over China. J. Geophys. Res. Atmos. 2016, 121, 716. [CrossRef]

50. Proestakis, E.; Amiridis, V.; Marinou, E.; Georgoulias, A.; Solomos, S.; Kazadzis, S.; Chimot, J.; Che, H.; Alexandri, G.; Binietoglou, I.; et al. Nine-year spatial and temporal evolution of desert dust aerosols over South and East Asia as revealed by CALIOP. Atmos. Chem. Phys. 2018, 18, 1337-1362. [CrossRef]

51. Liu, P.; Ye, C.; Xue, C.; Zhang, C.; Mu, Y.; Sun, X. Formation mechanisms of atmospheric nitrate and sulfate during the winter haze pollution periods in Beijing: Gas-phase, heterogeneous and aqueous-phase chemistry. Atmos. Chem. Phys. 2020, 20, 4153-4165. [CrossRef]

52. Wang, Y.; Yu, M.; Wang, Y.; Tang, G.; Song, T.; Zhou, P.; Liu, Z.; Hu, B.; Ji, D.; Wang, L.; et al. Rapid formation of intense haze episodes via aerosol-boundary layer feedback in Beijing. Atmos. Chem. Phys. 2020, 20, 45-53. [CrossRef]

53. Monks, P.S.; Archibald, A.T.; Colette, A.; Cooper, O.; Coyle, M.; Derwent, R.; Fowler, D.; Granier, C.; Law, K.S.; Mills, G.E.; et al. Tropospheric ozone and its precursors from the urban to the global scale from air quality to short-lived climate forcer. Atmos. Chem. Phys. 2015, 15, 8889-8973. [CrossRef]

54. Xie, S.; Wang, S.; Dao, X.; Zheng, H.; Hong, G.; Zhang, X. Analysis of Air Quality in Beijing-Tianjin-Hebei and Surrounding Areas During the Spring Festival of 2018. Environ. Monit. China 2019, 35, 1-11.

55. Xiao, C.; Chang, M.; Guo, P.; Gu, M.; Li, Y. Analysis of air quality characteristics of Beijing-Tianjin-Hebei and its surrounding air pollution transport channel cities in China. J. Environ. Sci. 2019, 87, 213-227. [CrossRef]

56. Zhang, X.; Zhang, Q.; Hong, C.; Zheng, Y.; Geng, G.; Tong, D.; Zhang, Y.; Zhang, X. Enhancement of PM 2.5 Concentrations by Aerosol-Meteorology Interactions Over China. J. Geophys. Res. Atmos. 2017, 1179-1194. [CrossRef]

57. Wang, H.; Jianghao, L.; Yue, P.; Meng, Z.; Huizheng, C.; Xiaoye, Z. The impacts of the meteorology features on PM2.5 levels during a severe haze episode in central-east China. Atmos. Environ. 2018, 197, 177-189. [CrossRef]

58. Ning, G.; Wang, S.; Ma, M.; Ni, C.; Shang, Z.; Wang, J.; Li, J. Characteristics of air pollution in different zones of Sichuan Basin, China. Sci. Total Environ. 2018, 612, 975-984. [CrossRef]

59. Zhang, L.; Guo, X.; Zhao, T.; Gong, S.; Xu, X.; Li, Y.; Luo, L.; Gui, K.; Wang, H.; Zheng, Y.; et al. A modelling study of the terrain effects on haze pollution in the Sichuan Basin. Atmos. Environ. 2019, 196, 77-85. [CrossRef]

60. Cai, W.; Ke, L.; Liao, H.; Wang, H.; Wu, L. Weather conditions conducive to Beijing severe haze more frequent under climate change. Nat. Clim. Chang. 2017, 7, 257-262. [CrossRef]

61. Zhong, J.; Zhang, X.; Yunsheng, D.; Wang, Y.; Liu, C.; Wang, J.; Zhang, Y.; Che, H. Feedback effects of boundary-layer meteorological factors on cumulative explosive growth of PM2.5 during winter heavy pollution episodes in Beijing from 2013 to 2016. Atmos. Chem. Phys. 2018, 18, 247-258. [CrossRef] 
62. Brasseur, G.P.; Xie, Y.; Petersen, A.K.; Bouarar, I.; Flemming, J.; Gauss, M.; Jiang, F.; Kouznetsov, R.; Kranenburg, R.; Mijling, B.; et al. Ensemble forecasts of air quality in eastern China-Part 1: Model description and implementation of the MarcoPolo-Panda prediction system, version 1. Geosci. Model Dev. 2019, 12, 33-67. [CrossRef]

63. Gu, J.B.; Chen, L.F.; Yu, C.; Li, S.S.; Tao, J.H.; Fan, M.; Xiong, X.Z.; Wang, Z.F.; Shang, H.Z.; Su, L. Ground-Level NO2 Concentrations over China Inferred from the Satellite OMI and CMAQ Model Simulations. Remote Sens. 2017, 9, 519. [CrossRef]

64. Wang, Y.Q.; Zhang, X.Y.; Sun, J.Y.; Zhang, X.C.; Che, H.Z.; Li, Y. Spatial and temporal variations of the concentrations of PM10, PM2.5 and PM1 in China. Atmos. Chem. Phys. 2015, 15, 13585-13598. [CrossRef]

65. Li, Z.; Guo, J.; Ding, A.; Liao, H.; Liu, J.; Sun, Y.; Wang, T.; Xue, H.; Zhang, H.; Zhu, B. Aerosol and boundary-layer interactions and impact on air quality. Natl. Sci. Rev. 2017, 4, 810-833. [CrossRef]

66. Theys, N.; De Smedt, I.; Yu, H.; Danckaert, T.; van Gent, J.; Hormann, C.; Wagner, T.; Hedelt, P.; Bauer, H.; Romahn, F.; et al. Sulfur dioxide retrievals from TROPOMI onboard Sentinel-5 Precursor: Algorithm theoretical basis. Atmos. Meas. Tech. 2017, 10, 119-153. [CrossRef]

67. Ma, Y.; Zhang, M.; Jin, S.; Gong, W.; Chen, N.; Chen, Z.; Yinbao, J.; Shi, Y. Long-Term Investigation of Aerosol Optical and Radiative Characteristics in a Typical Megacity of Central China During Winter Haze Periods. J. Geophys. Res. Atmos. 2019, 124, 12093-12106. [CrossRef]

68. Ding, J.; van der, A.R.; Mijling, B.; Levelt, P. Space-based NOx emission estimates over remote regions improved in DECSO. Atmos. Meas. Tech. 2017, 10, 925-938. [CrossRef]

(C) 2020 by the authors. Licensee MDPI, Basel, Switzerland. This article is an open access article distributed under the terms and conditions of the Creative Commons Attribution (CC BY) license (http://creativecommons.org/licenses/by/4.0/). 